\title{
Grzegorz Miernik
}

https://orcid.org/0000-0003-0924-7408

Uniwersytet Jana Kochanowskiego w Kielcach

\section{Listy samotnych matek. Społeczno-polityczne konteksty powstania funduszu alimentacyjnego w 1974 roku}

Zarys treści: Tekst opisuje problemy, jakie w świetle listów pisanych do urzędów centralnych dotykały matki samotnie wychowujące dzieci. Dramatyczna sytuacja ekonomiczna zmuszała je do poszukiwania pomocy u najwyższych władz. W wyniku społecznych nacisków w 1974 r. ekipa Edwarda Gierka powołała fundusz alimentacyjny.

Abstract: The text describes the problems that were faced by single mothers seen through the prism of letters written to central government offices. The dramatic economic situation forced them to seek help from the highest authorities. As a result of social pressure, in 1974, Edward Gierek's team established a child maintenance fund.

Słowa kluczowe: PRL, samotne matki, egzekucja alimentów, listy, skargi, fundusz alimentacyjny Keywords: Polish People's Republic, single mothers, recovery of child support, letters, complaints, Child Maintenance Fund

\section{Wprowadzenie}

Prowadząc studia nad historią Polski po II wojnie światowej, warto wykorzystywać źródła osobiste. Wiele informacji i ocen zawierają listy, które obywatele wysyłali do instytucji centralnych. Wiadomo, że urzędnicy przeglądający tę korespondencję zwykle porządkowali ją tematycznie. Wśród problemów regularnie poruszanych w listach były i te dotyczące życiowych trudności, z którymi musiały zmagać się samotne matki. Wątkiem przewodnim w tej korespondencji były kwestie alimentacyjne. Dla samotnych matek najważniejsze było zapewnienie dzieciom środków do życia. Mając na uwadze ważkość i skalę zjawiska, warto problem zbadać.

Od niepamiętnych czasów wiele kobiet z różnych powodów samotnie wychowywało swoje dzieci. Kwestia samotnego macierzyństwa była jednak przez wieki marginalizowana. W ostatnich kilku dekadach problemem zainteresowali się 
intelektualiści, aktywiści społeczni i politycy. Stał się też obszarem naukowych dociekań ${ }^{1}$ Z uwagi na występujące $\mathrm{w}$ tytule pojęcie - samotne matki, właściwe będzie jego zdefiniowanie. Jest taka potrzeba, bowiem w literaturze przedmiotu używa się kilku niemal równoznacznych terminów ${ }^{2}$. Na przykład, samotne matki to duża część zbiorowości definiowanej jak rodzina niepełna ${ }^{3}$. Samotna matka to matka niezamężna ${ }^{4}$. Samotna matka jako podmiot polityki społecznej, ekonomicznej i prawnej to jedyna żywicielka rodziny ${ }^{5}$. Niektórzy badacze używają terminu rodzina niepełna lub zamiennie rodzina samotnej matki. Należy odnotować, że obok rodziny niepełnej w piśmiennictwie specjalistycznym mamy rodzinę zdekompletowaną, rodzinę bez partnera, rodzinę rozbitą, rodzinę zrekonstruowaną, rodzinę problemową, a także rodzinę nienormalną, rodzinę niekompletną, rodzinę chorą społecznie ${ }^{6}$.

Centralną figurą w niniejszych rozważaniach jest samotna matka. Powodem samotnego macierzyństwa może być wdowieństwo, niezamężność, rozwód, separacja. Losową przyczyną samotnego macierzyństwa jest śmierć ojca dziecka. W takiej sytuacji kwestią wtórną jest, czy dziecko urodziło się w związku małżeńskim, czy pozamałżeńskim. Kolejne wymienione powody samotnego macierzyństwa - niezamężność, rozwód i separacja - wynikają z subiektywnych powodów. W wieku XX samotność kobiet była wynikiem osobistych wyborów, ale też tragicznym następstwem dwóch wojen światowych ${ }^{7}$. Wśród kobiet niemających męskiego partnera były też samotne matki. Szczególnym powodem samotnego macierzyństwa było urodzenie dziecka poczętego na skutek gwałtu. Liczbę takich przypadków trudno ustalić. W powojennej Polsce matki i ich dzieci zrodzone wskutek gwałtów czasu wojny znajdowały się w szczególnie trudnym położeniu ${ }^{8}$.

${ }^{1}$ Przeglądowego omówienia problematyki samotnego macierzyństwa dokonała B. Klich-Kluczewska w monografii Rodzina, tabu i komunizm w Polsce 1956-1989, Kraków 2015, rozdz. III, s. $71-119$.

${ }^{2}$ Ibidem, s. 86-89.

${ }^{3}$ Zob. m.in: D. Graniewska, K. Krupa, B. Balcerzak-Paradowska, Samotne matki, samotni ojcowie. O rodzinach niepetnych $w$ Polsce, Warszawa 1986; M. Jarosz, Dezorganizacja w rodzinie i społeczeństwie, Warszawa 1987, s. 81-94.

${ }^{4}$ Zob.: B. Balcerzak-Paradowska, B. Konerska, Sytuacja społeczna i materialna matek niezamężnych, Warszawa 1983.

${ }_{5}^{5}$ M. Jarosz, Samotne matki we współczesnym społeczeństwie polskim, w: Polityka społeczna. Uwarunkowania demograficzne, zadania, potrzeby, red. M. Latuch, M. Namysłowska, Warszawa 1980, s. 303.

${ }^{6}$ J. Pielkowa, Rodzina samotnej matki jako środowisko wychowawcze, Katowice 1983, s. 19.

7 M. Fidelis, Czy „nowy matriarchat”? Kobiety bez mężczyzn w Polsce po II wojnie światowej, w: Kobieta i rewolucja obyczajowa. Społeczno-kulturowe aspekty seksualności. Wiek XIX i XX. Zbiór studiów, red. A. Żarnowska, A. Szwarc, Warszawa 2006, s. 422; K. Korzeniecka, Samodzielne macierzyństwo - wybór czy konieczność?, „Forum Pedagogiczne” 2014, nr 2, s. 110.

${ }^{8}$ B. Klich-Kluczewska, P. Perkowski, Obiekty biopolityki? Zdrowie, reprodukcja i przemoc, w: K. Stańczak-Wiślicz, P. Perkowski, M. Fidelis, B. Klich-Kluczewska, Kobiety w Polsce 1945-1989. 
Cechą przemian demograficznych zachodzących w Polsce po II wojnie światowej był istotny przyrost naturalny. Szczególnie w pierwszej dekadzie rodziło się bardzo wiele dzieci. Później liczba urodzin malała. Wyraźny spadek miał miejsce na przełomie lat sześćdziesiątych i siedemdziesiątych, jednak do końca istnienia PRL liczba urodzin przekraczała pół miliona rocznie. W tej grupie były też urodzenia pozamałżeńskie. W ujęciu procentowym od początku lat sześćdziesiątych nie notowano tendencji wzrostowej ${ }^{9}$. Od połowy lat sześćdziesiątych do połowy siedemdziesiątych corocznie przychodziło na świat od 24 do 29 tys. dzieci ze związków nieformalnych. Stanowiło to około 4\% ogólnej liczby urodzeń. Charakterystyczne, że dzieci pozamałżeńskie rodziły przede wszystkim kobiety młode, a wskaźnik urodzeń pozamałżeńskich był wyższy w miastach ${ }^{10}$. Dokonujące się po II wojnie światowej przemiany obyczajowe skutkowały wzrostem liczby rozwodów. Potwierdzają to dane statystyczne. W 1950 r. doszło do 11 tys. rozwodów, a w 1974 r. było ich 39,7 tys. ${ }^{11} \mathrm{~W}$ powojennej rzeczywistości niepokojącym zjawiskiem było porzucanie (opuszczanie) dzieci przez jedno z rodziców i pozostawiania ich bez środków do życia. Zdecydowanie częściej decydowali się na to ojcowie. W konsekwencji rozwodów powstawały rodziny niepełne. W absolutnej większości były to matki z dziećmi. W $1970 \mathrm{r}$. takich niepełnych rodzin było 926 858, a w 1974 r. - $949390^{12}$. Samotne macierzyństwo, jak już zostało wspomniane, mogło też być spowodowane czynnikami losowymi lub świadomą decyzją kobiety. Dla matek samotnie wychowujących dzieci kwestią fundamentalną było posiadanie niezbędnych środków finansowych potrzebnych na ich utrzymanie. Wiele kobiet, chcąc te środki zapewnić, musiało w postępowaniu sądowym zabiegać o alimenty, które mieli płacić ojcowie.

Trzeba zwrócić uwagę na to, że spora grupa samotnych matek nie starała się o alimenty. Powody miały charakter obiektywny i subiektywny. Do tych obiektywnych można zaliczyć trudności z ustaleniem ojcostwa oraz brak możliwości wskazania miejsca pobytu ojca. Wśród subiektywnych warto wymienić te wynikające $\mathrm{z}$ ambicji niezamężnej matki, środowiskowego wstydu, a nawet niechęci do szkodzenia ojcu dziecka ${ }^{13}$.

Nowoczesność, równouprawnienie, komunizm, Kraków 2020, s. 387-395; M. Zaremba, Wielka trwoga. Polska 1944-1947. Ludowa reakcja na kryzys, Kraków 2012, s. 170-184; D. Graniewska, K. Krupa, B. Balcerzak-Paradowska, op. cit., s. 12.

9 D. Graniewska, K. Krupa, B. Balcerzak-Paradowska, op. cit., s. 9.

${ }^{10}$ B. Tryfan, Socjalne i prawne środki ochrony macierzyństwa na wsi, w: Socjalne i prawne środki ochrony macierzyństwa i rodziny, wybór materiałów D. Graniewska, Warszawa 1976, s. 126-127.

${ }^{11}$ H. Bogacka, A. Sobieszak, Rozwody w Polsce w latach 1950-1974 w świetle badań statystycznych, w: Wybrane zagadnienia patologii rodziny, red. M. Jarosz, Warszawa 1976, s. 100-101; E. Rosset, Rozwody, Warszawa 1986, s. 201.

12 Kobiety w Polsce. Podstawowe informacje Warszawa 1975, s. 76. Dla porównania niepełnych rodzin tworzonych przez ojca i dzieci było w 1970 r. 116 020, a w 1974 r. - 115 430, ibidem.

${ }_{13}$ D. Graniewska, K. Krupa, B. Balcerzak-Paradowska, op. cit., s. 16. 
O samotnym macierzyństwie w Polsce po II wojnie światowej napisano już sporo. Tymczasem kwestia zapewnienia środków finansowych dla dzieci samotnych matek w literaturze historycznej jest co najwyżej wzmiankowana. To kolejna przesłanka zachęcająca do zbadania, z jakimi problemami musiały się mierzyć kobiety, chcące zapewnić swoim dzieciom środki do życia.

Bezdyskusyjne jest stwierdzenie, że osoby samotnie wychowujące dzieci musiały zmagać się z wieloma trudnościami. Było już wspomniane, że konieczność wypełniania rodzicielskich obowiązków tylko przez jedno z rodziców, najczęściej matkę, wynikała $\mathrm{z}$ różnych losowych uwarunkowań. W niniejszych badaniach uwaga zostanie skoncentrowana na samotnych matkach prowadzących batalie o alimenty z ojcami, którzy nie poczuwali się do wypełniania obowiązków rodzicielskich i nie przekazywali środków na swoje dzieci. Dopiero w XX w. zaczęto tworzyć instytucjonalne rozwiązania służące nałożeniu obowiązku alimentacyjnego, czyli zapewnienia środków przeznaczonych na rzecz osoby niezdolnej do samodzielnego utrzymania $\operatorname{się}^{14}$. W niniejszych rozważaniach pojęcie "alimenty” zawężono do obowiązku przekazywania pieniędzy przez rodziców na rzecz ich niesamodzielnych dzieci. Zdecydowana większość zobligowanych do alimentacji to byli ojcowie. Tylko niewiele samotnych matek otrzymywało alimenty dobrowolnie płacone przez ojców bez sądowej decyzji ${ }^{15}$.

Kwestie dochodzenia ojcostwa, a następnie ubiegania się o alimenty umieścić można w rozbudowanym katalogu postulatów zgłaszanych przez ruchy postępowe dążące do równouprawnienia kobiet. Dzięki sufrażystkom, lewicowym partiom politycznym i związkom zawodowym, w toku batalii politycznych w pierwszych dekadach XX w. w kolejnych państwach - nie bez problemów - wprowadzano ustawowe zapisy o równych prawach dla kobiet i mężczyzn. Odbudowujące się po latach zaborów państwo polskie równouprawnienie obywateli bez względu na płeć podniosło do rangi normy konstytucyjnej. Stanowiąc kolejne akty prawne w II Rzeczypospolitej, potwierdzano równouprawnienie kobiet i konsekwentnie likwidowano dyskryminujące zapisy ustawowe państw zaborczych ${ }^{16}$. W praktyce uwarunkowania historyczne, w tym społeczne, kulturowe i religijne skutecznie hamowały procesy modernizacyjne, także te dotyczące równouprawnienia kobiet ${ }^{17}$. $\mathrm{Z}$ tego powodu kobiety mające dziecko nieślubne ${ }^{18}$ doświadczały opresyjnego

${ }^{14}$ Leksykon polityki społecznej, red. B. Rysz-Kowalczyk, Warszawa 2002, s. 15.

15 D. Graniewska, K. Krupa, B. Balcerzak-Paradowska, op. cit., s. 16.

${ }^{16}$ M. Pietrzak, Sytuacja prawna kobiet w Drugiej Rzeczypospolitej, w: Równe prawa i nierówne szanse. Kobiety w Polsce międzywojennej, red. A. Żarnowska, A. Szwarc, Warszawa 2000, s. 77-91.

17 D. Kałwa, Wyboiste drogi równouprawnienia. Sytuacja kobiet w II Rzeczypospolitej, w: A. Czocher, D. Kałwa, B. Klich-Kluczewska, B. Łabno, Wojna to męska rzecz? Losy kobiet w okupowanym Krakowie w dwunastu odsłonach, Kraków 2011, s. 8-13.

18 Było to potoczne określenie dzieci urodzonych w związkach pozamałżeńskich. W użyciu funkcjonowało więcej pojęć, które uznać należy za pejoratywne, obraźliwe wręcz wulgarne. 
traktowania. Prawo utrudniało bądź uniemożliwiało ustalenie ojcostwa. Podobnie bardzo trudne okazywało się uzyskanie alimentów. Konsekwencją tej dyskryminacji był brak środków do życia, co skutkowało bardzo wysoką śmiertelnością nieślubnych niemowląt ${ }^{19}$. Pod presją oświeconych przedstawicieli opinii publicznej podjęto prace legislacyjne mające poprawić położenie samotnych matek i ich nieślubnych dzieci ${ }^{20}$.

Podejmując tytułową problematykę, należy pamiętać o projektach dotyczących rodziny, aktywizacji zawodowej kobiet i macierzyństwa realizowanych w Polsce po II wojnie światowej. Wcześniej wiele z tych projektów wprowadzono w ZSRR, skąd po wojnie transferowano je do Polski i innych państw w radzieckiej strefie wpływów. W tym miejscu warto przypomnieć, że w pierwszych latach rządów bolszewickich instytucję małżeństwa deprecjonowano i określano jako przeżytek. Świadectwem rewolucji obyczajowej było przyzwolenie na nieskrępowane życie seksualne i powszechność zabiegów aborcyjnych. Po kilku latach dezawuowania tradycyjnych wartości i akceptowania obyczajowej rozwiązłości władze radzieckie zaczęly wspierać politykę pronatalistyczną. Chcąc podnieść liczbę urodzeń, wielu decydentów uznało, że należy finansowo wzmocnić rodzinę. Jednak forsowna industrializacja pochłaniała niemal wszystkie środki, których brakowało na odpowiednią opiekę i wsparcie dla dzieci. W latach trzydziestych działania mające wesprzeć rodzinę i promować macierzyństwo zostały potwierdzone rozwiązaniami legislacyjnymi. Osoby wnoszące o rozwód po raz drugi i trzeci musiały się liczyć z karami pieniężnymi. Zapewniono możliwości egzekwowania zobowiązań ojcowskich wobec dzieci. Przepisy z 1933 r. nakazywały rejestrację urodzin, a matka mogła podać dane personalne ojca niezależnie od tego, czy byli małżeństwem. W 1936 r. ustanowiono prawo, które zakazywało aborcji, utrudniało rozwód i zaostrzyło przepisy alimentacyjne. Minimalna kwota alimentów na jedno dziecko miała stanowić $25 \%$ pensji niezamężnego lub rozwiedzionego ojca. Na dwoje dzieci przypadała $1 / 3$, a na troje i więcej połowa wynagrodzenia ojca. Zaostrzono też przepisy wobec ojców uchylających się od płacenia alimentów, podnosząc karę do dwóch lat więzienia ${ }^{21}$. Należy podkreślić, że w kolejnych latach w ZSRR usilnie starano się poszukiwać ojców niepłacących alimentów ${ }^{22}$. Później dokonywano kolejnych modyfikacji przepisów dotyczących alimentów ${ }^{23}$.

19 M. Pietrzak, op. cit., s. 83.

${ }^{20}$ Ibidem, s. 81.

${ }^{21}$ D.L. Hoffman, Mothers in the motherland, Stalinism pronatalism in its pan-European context, „Journal of Social History” 34, 2000, nr 1, s. 44; W. Majdański, Planowanie zaludnienia. Self-control, Łomianki 2004, s. 395.

22 D.L. Hoffman, op. cit., s. 44-45.

${ }^{23}$ Kodeks prawa małżeńskiego, rodzinnego i opiekuńczego RSFRR. Tekst urzędowy według stanu na dzień 1 lipca 1950 r. wraz z Dodatkiem zawierającym materiały do poszczególnych artykułów kodeksu, Warszawa 1951, s. 68-72. 
Powracając do kwestii dotyczących aktywizacji zawodowej kobiet i wynikających z tego następstw w Polsce rządzonej przez partie komunistyczne - Polską Partię Robotniczą, a następnie Polską Zjednoczoną Partię Robotniczą - można uznać, że najważniejsze ustalenia zostały już opublikowane ${ }^{24}$.

W Polsce rządzonej przez komunistów plany gospodarcze najczęściej realizowano prostymi, ekstensywnymi sposobami. Dzięki temu rosło zatrudnienie. Duży udział w tym wzroście miały kobiety podejmujące pracę zawodową. Wzrost zatrudnienia kobiet i podejmowanie przez nie pracy zwykle wykonywanej przez mężczyzn, szczególnie w okresie stalinowskim, był propagandowo nagłaśnianym świadectwem równouprawnienia ${ }^{25}$. Wiele $\mathrm{z}$ nich, rozpoczynając pracę zawodową, znalazło się w nowym środowisku. Wyrwane $\mathrm{z}$ konserwatywnych wiejskich i małomiasteczkowych społeczności, pozbawione wsparcia rodziny, musiały dokonywać trudnych wyborów. Szczególnie dotyczyło to niezamężnych kobiet, które zaszły $\mathrm{w}$ ciążęe ${ }^{26}$. Jeśli z różnych powodów nie zawierały związku małżeńskiego, to ich sytuacja życiowa stawała się trudna, choć formalnie samotna matka miała zapewnioną pomoc państwa. Należy też podkreślić, że konstytucja PRL gwarantowała dzieciom urodzonym poza małżeństwem równe prawa $\mathrm{z}$ urodzonymi w związku małżeńskim ${ }^{27}$. Jednak w ówczesnych realiach dominowały tradycyjne normy obyczajowe i dlatego samotne matki były stygmatyzowane. To utrudniało dochodzenie należnych świadczeń, w tym alimentów. Podejmowanie pracy zawodowej i zdobywanie wykształcenia sprzyjało ekonomicznej samodzielności i niezależności kobiet. Nieliczne decydowały się na macierzyństwo bez zawierania związku małżeńskiego, ale i one mogły domagać się alimentów od ojca dziecka. Kwestia świadczeń alimentacyjnych pojawiała się też jako następstwo rozpadu małżeństwa. W większości przypadków, co było wzmiankowane, to mąż i ojciec zostawiał kobietę wraz z potomstwem. Sprawą wtórną było, czy związek został formalnie rozwiązany.

Przyjęty w PRL model rozwoju kraju wymuszał nie tylko tzw. produktywizację kobiet, ale też wzrost demograficzny. Chodziło o to, aby w kolejnych dekadach nie

${ }^{24}$ M. Fidelis, Kobiety, komunizm i industrializacja w powojennej Polsce, Warszawa 2015; N. Jarska, Kobiety $z$ marmuru. Robotnice $w$ Polsce $w$ latach 1945-1960, Warszawa 2015; D. Jarosz, Polacy a stalinizm 1948-1956, Warszawa 2000, rozdz. III, s. 116-144; M. Fidelis, Równouprawnienie czy konserwatywna nowoczesność? Kobiety pracujące, w: K. Stańczak-Wiślicz, P. Perkowski, M. Fidelis, B. Klich-Kluczewska, op. cit., s. 103-164; P. Perkowski, Wedded to Welfare? Working Mothers and the Welfare State in Communist Poland, „Slavic Review” 76, 2017, nr 2, s. 455-480; Z. Dach, Praca zawodowa kobiet $w$ Polsce $w$ latach 1950-1972 i jej aspekty ekonomiczno-społeczne, Warszawa 1976; R. Doniec, Rodzina polska w kulturze realnego socjalizmu. Między ideologia a codziennością, Kraków 2019.

25 A. Kurzynowski, Macierzyństwo a praca kobiet zamężnych (poza rolnictwem), w: Socjalne i prawne środki..., Warszawa 1976, s. 131; R. Doniec, op. cit., s. 233.

${ }^{26}$ N. Jarska, op. cit., s. 182.

27 Dz.U. 1952, nr 33, poz. 232, art. 67; J. Winiarz, Ochrona praw matki, dziecka i rodziny, Warszawa 1954, s. 31-32. 
zabrakło pracowników. Władze w Polsce, podobnie jak to miało miejsce w wielu innych państwach, dostrzegały konieczność promowania zachowań pronatalistycznych. Pochodną tego była konieczność wspierania rodziny, ale też samotnych matek. Decydenci partyjno-państwowi musieli to uwzględnić, określając cele polityki socjalnej.

Nie mogą dziwić starania samotnych matek, chcących zapewnić środki finansowe swoim dzieciom. W artykule przedstawiono opisane $w$ listach ich zabiegi celem nałożenia na ojców obowiązku alimentacyjnego. W wielu przypadkach dążenie do sądowego przyznania alimentów poprzedzone było trudnym, często upokarzającym postępowaniem o ustalenie ojcostwa. Równie ważną kwestią opisywaną przez matki samotnie wychowujące dzieci były trudności w egzekucji orzeczonych przez sądy zobowiązań alimentacyjnych. Listy dotyczące tych kwestii to najczęściej skargi, błagalne prośby, rzadko donosy. Co ważne i zrozumiałe, w tej grupie nie ma anonimów. Choć autorkami listów w absolutnej większości były samotne matki, to niektóre zostały napisane przez małoletnie dzieci skarżące się na wyrodnych ojców ${ }^{28}$. Warto zwrócić uwagę na narrację w listach wysyłanych przez samotne matki „do Warszawy”. Wielokrotnie są to dramatyczne opowieści o doznanych krzywdach, upokorzeniach. Autorki wskazują na skutki wynikające z niedostatków finansowych uniemożliwiających zaspokajanie podstawowych potrzeb bytowych. Indywidualne historie zawierają szczegółowe, często emocjonalne opisy wytrwałych, czasochłonnych, a i kosztowych zmagań celem zasądzenia i egzekucji alimentów. Przebadana korespondencja jest też źródłem informacji o funkcjonowaniu państwowej biurokracji. Chcąc na konkretnych przykładach pokazać trudności, z którymi musiały się mierzyć samotne matki i emocje, jakie temu towarzyszyły, w tekście zamieszczono wyjątki z listów.

Zasadniczy korpus spożytkowanych źródeł to niewielka część zespołów: Komitet Centralny (KC) PZPR przechowywanego w Archiwum Akt Nowych oraz Komitet do spraw Radiofonii „Polskie Radio”, a następnie Komitet do spraw Radia i Telewizji „Polskie Radio i Telewizja” przechowywanych w Ośrodku Dokumentacji i Zbiorów Programowych Telewizji Polskiej S.A. Każda z tych instytucji posiadała w swych strukturach wydzielone biuro zajmujące się obsługą napływających listów ${ }^{29}$. Dla władz korespondencja była ważnym kanałem dostarczającym

28 AAN, KC PZPR, XXVII/5, Notatka o niektórych problemach związanych z alimentacją, k. 229; ODiZP TVP, KdsRiT „Polskie Radio i Telewizja”, BL, 1050/72, „Biuletyn Wewnętrzny” nr 309, grudzień 1966, s. 3; ibidem, 1208/5/1, „Biuletyn Wewnętrzny” nr 466, październik 1968, s. 14-15; AAN, KC PZPR, XXVII/3, Informacja o listach, które wpłynęły do Biura Listów i Inspekcji w lutym 1973 r., k. 78-79.

29 G. Miernik, Listy do centralnych władz Polskiej Zjednoczonej Partii Robotniczej (1950-1989), w: A.M. Adamus, D. Jarosz, G. Miernik, E. Szpak, Listy do władz centralnych w Polsce 1945-1989 (przewodnik), Warszawa 2019, https://rcin.org.pl/ihpan/dlibra/publication/91801/edition/74556 (dostęp: 7 I 2022), s. 189-192; D. Jarosz, Listy do Polskiego Radia i Telewizji (1950-1989), w: ibidem, s. 10. 
informacji o tym, co trapiło obywateli, stając się też impulsem do podjęcia działań, aby poruszanym w listach problemom zaradzić. Efektem prac wspomnianych biur są archiwalia, w tym biuletyny zawierające informacje o liczbie listów, zgłaszanych problemach, sposobach załatwiania sygnalizowanych przez obywateli spraw. W owych biuletynach drukowano także wybrane fragmenty listów. Najczęściej korespondenci opisywali problemy osobiste, rzadziej dotyczące najbliższych czy lokalnych zbiorowości - wiejskich wspólnot, grup pracowniczych. Historycy sięgają po te cenne źródła przede wszystkim w badaniach codziennych problemów realiach PRL. Trzeba podkreślić, że w PRL wysyłanie listów do instytucji partyjno-państwowych było wypracowaną koncepcją, mającą spowodować interwencję, naprawienie krzywd, uzyskanie pomocy. Zwykle autorzy listów osiągali pożądany efekt, co potwierdzało skuteczność strategii pisania „do Warszawy”.

Prowadząc badania, zapoznano się z materiałami archiwalnymi dotyczącymi dwóch dekad - od połowy lat pięćdziesiątych do chwili uchwalenia ustawy o funduszu alimentacyjnym 18 lipca 1974 r. Rezultaty prac dotyczących tego okresu zawiera niniejszy artykuł.

Celem badań było uzyskanie odpowiedzi na kilka zasadniczych pytań i ustalenie: jak często tematyka alimentacyjna była poruszana w listach „do Warszawy”? Kto i dlaczego pisał o kwestiach alimentacyjnych? Jakich argumentów używali korespondenci, przedstawiając swoje racje? Jakie działania podejmowano, aby uzyskać prawo do świadczeń alimentacyjnych? Jak postępowano, gdy zobowiązani do alimentacji unikali przekazywania pieniędzy dla swoich dzieci? Jak opisywano i oceniano efektywność oraz zaangażowanie instytucji państwowych - sądów, prokuratur, komorników, MO, zakładów karnych oraz zakładów pracy w rozwiązywanie problemów wynikających z niepłacenia alimentów? Czy sytuacje opisywane w listach były sprawdzane? Czy strategia pisania skarg i próśb w sprawach alimentacyjnych do centralnych peerelowskich instytucji była skuteczna? Jakie były okoliczności wprowadzenia prawnych rozwiązań zapewniających wypłacanie alimentów w przypadkach unikania tego obowiązku przez osoby zobowiązane wyrokiem sądu?

\section{Podstawowe informacje o liczbie listów i autorach}

Było już wspomniane, że w ogromnej masie przesyłek docierających do wymienionych biur listów urzędów centralnych sporą grupę stanowiły te dotyczące alimentów. W jednym z biuletynów, opracowanym przez Biuro Listów Komitetu do spraw Radiofonii „Polskie Radio” z 1957 r. podawano, że sprawy alimentacyjne 
stanowiły „żelazną pozycję” w napływającej „od lat” korespondencji ${ }^{30}$. W kolejnych latach było podobnie. W 1960 r. do radia i telewizji przysłano ok. 2300 listów w sprawach alimentacyjnych ${ }^{31}$. W 1961 r. - 2426, a w 1962 r. - 2941 ${ }^{32}$. Do Biura Listów Komitetu do spraw Radia i Telewizji „Polskie Radio i Telewizja” w 1964 r. wpłynęło 2476 listów dotyczących problemów z alimentami, a w 1965 r. - $2305^{33}$. W następnym, 1966 r., zarejestrowano 2047 skarg i próśb o pomoc w uzyskaniu tych świadczeń ${ }^{34}$. Rok później takich listów otrzymano $2207^{35}$. Na początku lat siedemdziesiątych do Biura Listów Komitetu do spraw Radiofonii i Telewizji „Polskie Radio i Telewizja” wpłynęło ok. 1500 listów dotyczących spraw alimentacyjnych. Kwestia ta pojawiała się także w korespondencji przy okazji przedstawiania innych spraw $^{36}$. Listy dotyczące niepłacenia alimentów, najczęściej przez ojców, którzy porzucili rodzinę, a nierzadko odbywających karę więzienia, napływały także do KC PZPR ${ }^{37}$. Większość tych dotyczących kwestii alimentacyjnych adresowano do I sekretarza KC PZPR ${ }^{38}$.

Z informacji opracowanej przez Biuro Listów Komitetu do spraw Radia i Telewizji wynika, że na początku lat siedemdziesiątych o sprawach alimentacyjnych najczęściej pisały mieszkanki wsi definiowane jako rolniczki (53,2\% spraw), następnie robotnice (32,3\%), najrzadziej zaś pracownice umysłowe $(14,5 \%)^{39}$.

Skargi i prośby napisane przez samotne matki kierowane do biur listów, organizacji polityczno-społecznych, urzędów czy redakcji gazet miały spowodować zajęcie się sprawą. I tak się działo. W przebadanej korespondencji odnaleziono sporo pism zawierających wyjaśnienia z urzędów zajmujących się sprawami alimentacyjnymi. Były wśród nich listy prezesów sądów, prokuratorów, komorników.

30 ODiZP TVP, Komitet do spraw Radiofonii „Polskie Radio”, BL, 1050/20, t. 1, „Biuletyn” nr 39 z 1 VI 1957, k. 200.

31 ODiZP TVP, KdsRiT „Polskie Radio i Telewizja”, BL, 1050/35, Notatka w sprawie alimentów, I cz., Warszawa, 16 III 1961, s. 1. W dokumencie z 1963 r. podano, że w 1960 r. wpłynęło 2536 listów. Zob: ibidem,1050/42, Serwis Biura Listów nr 80, Umarł król - niech żyje król (podzwonne 201 art. k.k.), Warszawa, maj 1963, s. 2.

32 ODiZP TVP, KdsRiT „Polskie Radio i Telewizja”, BL, 1050/42, Serwis Biura Listów nr 80, Umarł król - niech żyje król (podzwonne 201 art. k.k.), Warszawa, maj 1963, s. 2.

33 ODiZP TVP, KdsRiT „Polskie Radio i Telewizja”, BL, 1050/72, „Biuletyn Wewnętrzny” nr 309, grudzień 1966, s. 3.

34 ODiZP TVP, KdsRiT „Polskie Radio i Telewizja”, BL, 1207/3, „Biuletyn Wewnętrzny” nr 315, luty 1967, s. 1.

35 ODiZP TVP, KdsRiT „Polskie Radio i Telewizja”, BL, 1208/1/2, „Biuletyn Wewnętrzny” nr 409, luty 1968, s. 1; ibidem, 1208/5/1, „Biuletyn Wewnętrzny” nr 466, październik 1968, s. 1.

${ }^{36}$ ODiZP TVP, KdsRiT „Polskie Radio i Telewizja”, BL, 1231/3, „Biuletyn Wewnętrzny” nr 9 (607), kwiecień 1972, O egzekucji alimentów, cz. 1, oprac. red. B. Kwiecień, s. 5.

37 AAN, KC PZPR, 237/XXV-55, Sprawozdanie BLiI KC PZPR za rok 1966, k. 54.

38 AAN, KC PZPR, XXVII/5, Notatka o niektórych problemach związanych z alimentacją, k. 229.

39 ODiZP TVP, KdsRiT „Polskie Radio i Telewizja”, BL, 1231/3, „Biuletyn Wewnętrzny” nr 9 (607), kwiecień 1972, O egzekucji alimentów, cz. 1, oprac. red. B. Kwiecień, s. 5. 


\section{Dochodzenie zobowiązań alimentacyjnych w postępowaniu procesowym}

W analizowanym okresie kwestię alimentacyjnego obowiązku rodziców wobec dzieci regulowały ustawy: kodeks rodzinny z $1950 \mathrm{r} .^{40}$, a następnie kodeks rodzinny i opiekuńczy z $1964 \mathrm{r}^{41}$ Ważny był też kodeks postępowania cywilnego z $1930 \mathrm{r}$., w okresie powojennym kilkakrotnie nowelizowany ${ }^{42}$, a w 1964 r. zastąpiony nową ustawą $^{43}$. Wobec opornych ojców, a bardzo rzadko matek stosowano artykuł 201 kodeksu karnego z 1932 r. ${ }^{44}$ W nowym kodeksie karnym uchwalonym w 1969 r. znalazł się artykuł 186 dotyczący kwestii karania osób uchylających się przed płaceniem zasądzonych alimentów ${ }^{45}$. Teoretycy i praktycy podejmujący kwestię alimentacji w peerelowskiej literaturze wielokrotnie podkreślali wyższość rozwiązań przyjętych w państwie socjalistycznym nad obowiązującymi w „prawie burżuazyjnym” ${ }^{46}$.

W ujęciu prawnym problemy alimentacji dotyczyły:

1. Orzekania o obowiązku i zakresie alimentacji.

2. Egzekwowania zasądzonych od dłużnika świadczeń alimentacyjnych.

3. Sankcji karnej za uchylanie się od obowiązku alimentacyjnego ${ }^{47}$.

Wymienione powody skłaniały samotne matki do wszczynania sądowych postępowań o alimenty. Dostępne informacje pozwalają określić skalę zjawiska. W 1955 r. w sądach cywilnych rozpatrywano 22459 spraw o alimenty, a w 1974 r. 69 861. Liczba takich spraw sądowych w okresie 1955-1974 wzrosła ponad trzykrotnie. Do tego należy dodać od 7 tys. do 8,5 tys. corocznie prowadzonych postępowań sądowych o zasądzenie alimentów w sprawach o ustalenie ojcostwa. O obowiązku alimentacyjnym orzekały też sądy prowadzące postępowania rozwodowe ${ }^{48}$. Trzeba jednak pamiętać, że wielu mężczyzn po rozwodzie lub rozstaniu z matką swoich dzieci zakładało drugą rodzinę i zwykle rodziły się kolejne dzieci. W takiej sytuacji ściąganie alimentów odbywało się niejako kosztem potomstwa $\mathrm{z}$ drugiego $\mathrm{związku}^{49}$. Zebrane dane świadczą nie tylko

40 Dz.U. 1950, nr 34, poz. 308.

${ }^{41}$ Dz.U. 1964, nr 9, poz. 59.

42 Dz.U. 1930, nr. 83, poz. 651; Dz.U. 1958, nr 18, poz. 75; Dz.U. 1962, nr 10, poz. 46.

${ }^{43}$ Dz.U. 1964, nr 43, poz. 296.

${ }^{44}$ Dz.U. 1932, nr 60, poz. 571, art. 201.

45 Dz.U. 1969, nr 13, poz. 94, art. 186.

${ }^{46}$ M. Gersdorf, I. Sabat, W. Szczepłek, J. Zabłocka, Efektywność egzekucji roszczeń alimentacyjnych oraz sadowe dochodzenie ojcostwa. Wybrane problemy, Warszawa 1976, s. 3-4.

47 ODiZP TVP, KdsRiT „Polskie Radio i Telewizja”, BL, 1050/35, Notatka dla obywatela Ministra M. Rybickiego sporządzona stosownie do polecenia z dnia 19 III 1961, s. 1-8.

${ }^{48}$ M. Andrzejewski, Fundusz alimentacyjny. Komentarz do ustawy z dnia 18 lipca 1974 r., Lublin 1995, s. 13-14.

49 Zwracała na to uwagę Zofia Dębińska na sympozjum, które odbyło się w kwietniu 1973 r. Zob.: Socjalne i prawne środki ochrony macierzyństwa i rodziny. Sympozjum - 9 IV 1973. Dyskusja, Warszawa 1973, s. 42. 
o rosnącej liczbie spraw alimentacyjnych, ale prawnych i społeczno-ekonomicznych tego konsekwencjach.

Dla peerelowskich władz w połowie lat pięćdziesiątych nie było tajemnicą, że wymiar sprawiedliwości „marginalnie” traktował sprawy alimentacyjne. Działo się tak mimo zapisów ustawowych i deklaracji o ochronie praw matki i dziecka. Zwykle sądy nie udzielały należytej pomocy kobietom składającym pozwy przeciwko ojcom uchylającym się od świadczeń na rzecz dzieci. Powódki skarżyły się, że sądy wbrew ustawie oczekiwały, a czasami wręcz żądały, aby odnalazły ojca dziecka, podały adres zamieszkania. Jeśli nie ustalono miejsca pobytu ojca, który porzucił dzieci, a w konsekwencji nie dostarczono wezwania, to sąd odraczał rozprawy. Nawet prezesi sądów potwierdzali, że procesy ciągnęły się latami, bo nie można było pozwanemu doręczyć wezwania na rozprawę, obecność zaś pozwanego była konieczna, aby wydać wyrok ${ }^{50}$.

Sądy w takich sprawach miały ograniczone możliwości poszukiwania pozwanych. Mogło być ono prowadzone za pośrednictwem milicyjnych Biur Ewidencji i Ruchu Ludności. W postępowaniu cywilnym tak sąd, jak i prokuratura nie mogły wydać listu gończego czy też stosować tymczasowego aresztowania ${ }^{51}$. Jak wynika $\mathrm{z}$ analizy listów, matki samotnie wychowujące dzieci nie mogły zrozumieć, dlaczego za przestępcami unikającymi płacenia alimentów nie wystawiano listów gończych ${ }^{52}$.

Zdarzało się, że niektórzy mężczyźni jeszcze przed sądową rozprawą o ustalenie ojcostwa opuszczali „bez śladu” swoje dotychczasowe miejsce zamieszkania. Takie postępowanie było celowe. Zdesperowane kobiety na własną rękę podejmowały poszukiwania, nie uzyskując żadnej pomocy od instytucji państwowych. Opisywała to Feliksa z powiatu Opole Lubelskie. Skarżyła się, jak wiele matek samotnie wychowujących dzieci, że nie było jej stać na jeżdżenie po całym kraju w poszukiwaniu ojca dziecka. Prezes sądu powiatowego w Zamościu, gdzie prowadzono postępowanie wyjaśniał, że procedowanie nie mogło być prowadzone bez dostarczenia wezwania ojcu. Jednak milicja przez wiele miesięcy nie znalazła poszukiwanego inżyniera Szymona S. Pozwany „zmieniał miejsce zamieszkania nie pozostawiając po sobie śladu”53.

Długotrwałe postępowania procesowe powodowały, że osoby ubiegające się o zasądzenie alimentów, czekając na wyrok przez wiele miesięcy, pozostawały bez środków do życia. Należy też podkreślić, że z powodu braku odpowiednich przepisów sądy, skazując ojców za inne przestępstwa, nie wydawały równocześnie orzeczenia o obowiązku alimentacji ${ }^{54}$.

50 ODiZP TVP, KdsRiT „Polskie Radio i Telewizja”, BL, 1050/35, Notatka w sprawie alimentów, I cz., Warszawa, 16 III 1961, s. 1.

${ }^{51}$ Ibidem, s. 1.

52 ODiZP TVP, KdsRiT „Polskie Radio i Telewizja”, BL, 1208/5/1, „Biuletyn Wewnętrzny” nr 466, październik 1968, s. 7.

53 ODiZP TVP, KdsRiT „Polskie Radio i Telewizja”, BL, 1050/72, „Biuletyn Wewnętrzny” nr 309, grudzień 1966, s. 3-5.

54 AAN, KC PZPR, XXVII/5, Notatka o niektórych problemach związanych z alimentacją, k. 236. 


\section{Postępowania sądowe o egzekucję alimentów}

Uzyskanie prawomocnego wyroku sądowego $\mathrm{w}$ sprawach o alimenty w wielu przypadkach nie gwarantowało regularnego otrzymywania pieniędzy na dziecko. Pracownicy Biura Listów i Inspekcji KC PZPR informowali, że w grupie spraw dotyczących „zagadnień prawnych” większość skarg dotyczyła przypadków nierespektowania wyroków sądów i celowego, wręcz złośliwego uchylania się od płacenia alimentów na dzieci ${ }^{55}$. Ojcowie na różne sposoby unikali wywiązywania się z obowiązków alimentacyjnych. Jak było wspomniane, powszechną praktyką były ucieczki przed wymiarem sprawiedliwości od swoich dzieci i ich matek. Często mężczyźni, na których ciążył obowiązek płacenia alimentów, ukrywali się. Mimo obowiązku meldunkowego nie było to takie trudne. Znalezienie nowego zatrudnienia $\mathrm{w}$ sytuacji deficytu siły roboczej w wielu branżach było łatwe, co wykorzystywali skazani. Taktyka porzucania pracy i zatrudniania się w innym miejscu była rozpowszechnionym i skutecznym sposobem utrudniającym ściąganie alimentów. Mężczyźni chcący uniknąć płacenia stosowali i inne metody. Najprostszą było bezrobocie lub dorywcze zarobkowanie. Wielu pracowało w zakładach prywatnych, których właściciel często nie dopełniał wymaganych procedur, a nawet nie informował urzędów kogo zatrudnia ${ }^{56}$.

Porzucone żony, rozwódki, samotne matki pozostające bez środków do życia podejmowały działania, aby wyegzekwować alimenty. Dlatego ponownie składały pozwy w sądach, wnosząc o egzekucję zasądzonych kwot. Zwykle postępowanie trwało jeszcze dłużej niż w sprawach o alimenty. Skalę problemu ukazują dane zebrane w tabeli 1 .

Tabela 1. Sprawy alimentacyjne w egzekucji cywilnej w latach 1955-1974

\begin{tabular}{|c|c|c|c|c|c|}
\hline \multirow{2}{*}{ Rok } & \multirow{2}{*}{$\begin{array}{c}\text { Wpływ spraw } \\
\text { alimentacyjnych } \\
\text { do egzekucji } \\
\text { cywilnej }\end{array}$} & \multicolumn{2}{|c|}{$\begin{array}{c}\text { Sprawy alimentacyjne w toku } \\
\text { postępowania w egzekucji cywilnej }\end{array}$} & \multirow{2}{*}{$\begin{array}{c}\text { Sprawy } \\
\text { ubiegłego } \\
\text { okresu }\end{array}$} \\
\cline { 3 - 5 } 1955 & 60985 & 99565 & 45612 & 53953 & 38580 \\
\hline 1960 & 48478 & 129909 & 37648 & 92261 & 81431 \\
\hline 1965 & 57954 & 196459 & 44630 & 151829 & 139405 \\
\hline 1970 & 65638 & 251954 & 51482 & 200472 & 186316 \\
\hline 1974 & 69015 & 309378 & 56094 & 253284 & 240363 \\
\hline
\end{tabular}

Źródło: M. Andrzejewski, Fundusz alimentacyjny. Komentarz do ustawy z dnia 18 lipca 1974 r., Lublin 1995, s. 14.

55 AAN, KC PZPR, 237/XXV-55, Sprawozdanie BLiI KC PZPR za rok 1966, k. 58.

56 AAN, KC PZPR, XXVII/5, Notatka o niektórych problemach związanych z alimentacją, k. 233. 
Jak wynika z powyższego zestawienia, liczba spraw o egzekucję zasądzonych alimentów stale rosła. Poważnym problemem była przewlekłość tych postępowań. Procesy trwały miesiącami, a nawet latami. Powody długotrwałego procedowania były takie same jak w przypadkach spraw o ustalenie alimentów. Zobowiązani do ich płacenia stosowali wypracowane, niewyszukane, ale sprawdzone sposoby unikania stawienia się na rozprawie w sądzie. Skutecznie ukrywali się, zmieniali miejsce pobytu, nie dopełniali obowiązku meldunkowego ${ }^{57}$, dlatego nie można było dostarczyć wezwania do sądu. W tym czasie opiekunowie, najczęściej samotne matki, nie otrzymywały alimentów na dzieci. Z tego powodu wiele niepełnych rodzin znalazło się w trudnej sytuacji. W skrajnych przypadkach zostały zepchnięte w obszary ubóstwa. Potwierdzają to liczne listy nadsyłane do różnych instytucji i prasy.

W listach do peerelowskich urzędów kobiety składające pozwy o egzekucję i podwyższenie alimentów skarżyły się na obciążanie ich opłatami sądowymi. Musiały też pokrywać koszty procesów prowadzonych w drugiej instancji. Starając się ustalić miejsce pobytu ojców, płaciły za swoje podróże, listy, telegramy. Korespondentki żaliły się na te obciążenia finansowe, które potęgowały kłopoty materialne ${ }^{58}$.

Przeprowadzone badania ujawniły, że w grupie listów dotyczących alimentów, przychodzących do centralnych instytucji najwięcej dotyczyło trudności w uzyskaniu wyroku o przyznaniu alimentów oraz wyegzekwowania prawomocnych wyroków ${ }^{59}$. W analizie przygotowanej w 1972 r. przez Biuro Listów Komitetu do spraw Radia i Telewizji podawano, że ten problem poruszano w 73\% ogółu listów dotyczących alimentów ${ }^{60}$. Gdy na początku lat siedemdziesiątych debatowano nad sposobami umacniania rodziny i ochrony dzieci, podpułkownik Leon Śliwiński z Komendy Głównej MO, wskazując na długie trwanie procesów alimentacyjnych, domagał się, aby je „usprawnić", podobnie postulowal „usprawnienie ściągania alimentów”61.

\section{Egzekucje alimentów przez komorników}

W sytuacji, gdy zobowiązany prawomocnym wyrokiem do płacenia alimentów dobrowolnie nie wywiązywał się z tego obowiązku, egzekucję miał przeprowadzić

57 AAN, KC PZPR, 237/XXV-55, Sprawozdanie BLiI KC PZPR za rok 1966, k. 59; ibidem, XXVII/3, Informacja o listach, które wpłynęły do Biura Listów i Inspekcji w lutym 1973, k. 79.

58 ODiZP TVP, KdsRiT „Polskie Radio i Telewizja”, BL, 1208/5/1, „Biuletyn Wewnętrzny” nr 466, październik 1968, s. 8-9; ibidem, 1208/1/2, „Biuletyn Wewnętrzny” nr 409, luty 1968, s. 6-7; AAN, KC PZPR, XXVII/3, Informacja o listach, które wpłynęły do Biura Listów i Inspekcji w lutym 1973, k. 78

59 ODiZP TVP, KdsRiT „Polskie Radio i Telewizja”, BL, 1050/35, Notatka w sprawie alimentów, I cz., Warszawa, 16 marca 1961, s. 1.

60 ODiZP TVP, KdsRiT „Polskie Radio i Telewizja”, BL, 1231/3, „Biuletyn Wewnętrzny” nr 9 (607), kwiecień 1972, O egzekucji alimentów, cz. 1, oprac. red. B. Kwiecień, s. 5.

${ }^{61}$ Socjalne i prawne środki ochrony macierzyństwa i rodziny. Sympozjum..., s. 28. 
komornik. Wielokroć urzędnik ten działał jednak wyjątkowo opieszale, o czym świadczą liczne skargi. Korespondencja nadchodząca do różnych peerelowskich instytucji zawiera wiele przykładów stosowania wspomnianych strategii, aby nie płacić na dzieci. Komornik, nie znając miejsca pobytu dłużnika, nie wszczynał egzekucji. Unikający płacenia alimentów podejmowali się doraźnych zajęć bez zawierania umów. W takich sytuacjach komornik nie mógł zająć poborów na poczet niezapłaconych alimentów ${ }^{62}$.

Zdając sobie sprawę z trudności w ściąganiu należności, władze dokonały zmian ustawowych mających poprawić skuteczność działań komorniczych. Uchwalony w listopadzie $1964 \mathrm{r}$. kodeks postępowania cywilnego nakładał na sądy i komorników działania z urzędu celem ustalenia miejsca zamieszkania i źródeł dochodów dłużnika alimentacyjnego ${ }^{63}$.

Przebadana korespondencja zawiera informacje o niechętnym przystępowaniu urzędników do egzekucji. Komornicy unikali osobistych kontaktów z dłużnikami. Niejednokrotnie takie postępowanie wynikało z wcześniejszych doświadczeń. Zdarzały się bowiem przypadki pobicia, byli oni narażeni na wyzwiska, obelgi tak ze strony dłużników, jak i ich bliskich. Z tych powodów komorników chroniła milicja. W skargach na nich ujawniano też przypadki rezygnacji z egzekucji bez „istotnych powodów”. Bywało, że egzekutorzy przetrzymywali tytuły wykonawcze miesiącami. Samotne matki bulwersowała bierność urzędników, choć, jak listownie informowały, dłużnik mieszkał i pracował w sąsiedztwie kancelarii komorniczej. Narzekały na wygodnictwo komorników. Wielokroć okazywało się, że gdy warunki atmosferyczne były złe i dotarcie do dłużnika było uciążliwe, to komornik odkładał egzekucję. Takie opieszałe postępowanie wykorzystywali dłużnicy, którzy wiedząc o mającej nastąpić egzekucji sprzedawali lub ukrywali cenne rzeczy czy też inwentarz żywy. Tymczasem komornicy, dbając o swój interes, zgodnie z proceduralnymi wymogami wysyłali do wierzycieli zawiadomienia: „egzekucja do skutku nie doszła z braku ruchomości podlegających zajęciu"64.

Skargi na długie procedury egzekucyjne, biurokratyczną bezduszność czy wręcz bezczynność komorników odnajdujemy w wielu listach. Zdarzało się, że postępowaniom egzekucyjnym $\mathrm{z}$ błahych powodów nie nadawano biegu. Wiadomo też o ignorowaniu wniosków i zażaleń adresowanych do komorników. Niemało pism pozostawało bez odpowiedzi. Dopiero pod naciskiem

62 ODiZP TVP, KdsRiT „Polskie Radio i Telewizja”, BL, 1050/35, Notatka w sprawie alimentów, I cz., Warszawa, 16 III 1961, s. 4; AAN, KC PZPR, XXVII/5, Notatka o niektórych problemach związanych z alimentacją, k. 233.

${ }^{63}$ Dz.U. 1964, nr 43, poz. 296, art. 1085 i 1086; Z. Wasilkowska, Prawna ochrona rodziny, w: Socjalne i prawne środki..., Warszawa 1976, s. 157-158.

${ }^{64}$ ODiZP TVP, KdsRiT „Polskie Radio i Telewizja”, BL, 1208/1/2, „Biuletyn Wewnętrzny” nr 409, luty 1968 , s. 1-2. 
swoich przełożonych - prezesów sądów powiatowych - komornicy podejmowali czynności ${ }^{65}$.

Korespondentki często skarżyły się na nieudolne, długotrwałe egzekucje alimentów. Anna z Opoczna po 15 latach „domowego piekła” opuściła gospodarstwo, zabierając ze sobą dwójkę dzieci. Podjęła nisko płatną pracę i żyła w trudnych warunkach. Nalegała, aby komornik zajął się egzekucją alimentów, a ten po roku poinformował, że ogłosił licytację motocykla dłużnika. Do licytacji jednak nie doszło, bowiem motor został wcześniej sprzedany. Po interwencji Biura Listów Komitetu do spraw Radia i Telewizji prezes sądu w Pasłęku radził interesantce złożenie wniosku o wykonanie zawieszonej warunkowo kary więzienia ${ }^{66}$. Korespondentka Zofia, zamieszkała w powiecie Radzyń Podlaski, skarżyła się na komornika, który kilkakrotnie deklarował wszczęcie egzekucji, jednak do dłużnika nie pojechał. Autorka listu uważała, że celowo nie podjął on działań, a ją oszukiwał ${ }^{67}$. Podobne doświadczenia miała inna korespondentka, która twierdziła, że komornik doradzał dłużnikowi, aby płacił nawet niewielkie kwoty, a w ten sposób uniknie egzekucji ${ }^{68}$. Julia z Suwałk skarżyła się na nieskuteczność komornika z Radzynia Podlaskiego. Ten w przesłanym piśmie wyjaśnił petentce, że podjęcie czynności egzekucyjnych było trudne, gdyż dłużnik jeździł do pracy. Przez cztery miesiące urzędnik nie mógł ustalić miejsca zatrudnienia i dokonać zajęcia poborów. $\mathrm{W}$ innym piśmie podawał, że dłużnik przebywał w areszcie śledczym. Po interwencji zwierzchnik komornika, prezes sądu stwierdził: „Komornik wykazał wielkie zaniedbanie w niniejszej egzekucji, dlatego zwróciłem mu uwagę za jego opieszałość" ${ }^{69}$. Podobne przypadki opisano w wielu listach.

Nierzadko okazywało się, że prezesi sądów, którym podlegali komornicy, również byli pasywni. Prezes Sądu Powiatowego w Tarnowie, odpowiadając na pismo Biura Listów Polskiego Radia w związku ze skargą na egzekucję zasądzonych w 1955 r. alimentów wyjaśnił, że komornik zajął wynagrodzenie zatrudnionego w Miejskim Przedsiębiorstwie Gospodarki Komunalnej w Tarnowie i świadczenia te były wypłacane do grudnia 1956 r., po czym z nieznanych powodów wypłata kolejnych została przerwana. Choć komornik skierował pismo do zakładu pracy, domagając się wyjaśnienia zaistniałej sytuacji, to nie otrzymał odpowiedzi. W związku z tym prezes sądu radził: „gdyby Obywatelka miała wiadomość, gdzie obecnie pracuje Michał S., proszę o podanie tej wiadomości komornikowi

\footnotetext{
${ }^{65}$ Ibidem, s. 9-18.

${ }^{66}$ ODiZP TVP, KdsRiT „Polskie Radio i Telewizja”, BL, 1231/3, „Biuletyn Wewnętrzny” nr 9 (607), kwiecień 1972, O egzekucji alimentów, cz. 1, oprac. red. B. Kwiecień, s. 10.

67 Ibidem, s. 11.

68 ODiZP TVP, KdsRiT „Polskie Radio i Telewizja”, BL, 1208/1/2, „Biuletyn Wewnętrzny” nr 409, luty 1968, s.12.

69 ODiZP TVP, KdsRiT „Polskie Radio i Telewizja”, BL, 1231/3, „Biuletyn Wewnętrzny” nr 9 (607), kwiecień 1972, O egzekucji alimentów, cz. 1, oprac. red. B. Kwiecień, s. 12-13.
} 
i o ewentualne postawienie wniosku o wszczęcie egzekucji z ruchomości dłużnika”. To jeden z wielu przykładów pozostawienia samotnej matki bez należytego wsparcia ze strony organów państwa.

Prezesów sądów powiatowych, będących zwierzchnikami komorników, krytykowano też za biurokratyczne, długotrwałe rozpatrywanie skarg dotyczących pracy podległych im urzędników. Nawet na interwencje biur listów centralnych instytucji odpowiadali niespiesznie ${ }^{70}$.

Jak wielkim problemem była egzekucja niezapłaconych alimentów świadczą dane z końca $1971 \mathrm{r}$. W tym czasie w urzędach komorniczych zarejestrowane były 216062 sprawy o egzekucję. Tylko w 1971 r. wpłynęło 68070 nowych. Komornicy prowadzili 177043 postępowania. Łatwo ustalić, że w 39019 przypadkach nie podjęto egzekucji. Działo się tak przede wszystkim z wymienionych powodów: braku danych o miejscu pracy i pobytu dłużnika. Komornicy wielokrotnie z tych właśnie powodów kończyli postępowanie, od poszkodowanych żądając ustalenia miejsca pobytu dłużnika. Sami nie współpracowali z milicją w poszukiwaniach osób niepłacących alimentów. Zaprezentowane i, co istotne, znane władzom informacje nie tylko obrazowały problemy z egzekucją należnych alimentów, ale uświadamiały konieczność wprowadzenia skutecznych sposobów zapewniających dzieciom i ich matkom stałego, pewnego otrzymywania pieniędzy niezależnie od efektywności postępowań komorniczych ${ }^{71}$.

\section{Działania prokuratury i milicji wobec uchylających się od wypełniania obowiązku alimentacji}

Poszukiwaniem ojców uchylających się od świadczenia na dzieci miały zajmować się prokuratury i MO, ale postępowania te bywały długotrwałe, zajmowały „od kilku miesięcy do kilku lat"72. Skargi i prośby nadsyłane do instytucji przez samotne matki zawierają szczegółowe opisy rutynowego, biurokratycznego prowadzenia takich spraw. W wielu przypadkach świadczą o ignorowaniu obowiązków przez funkcjonariuszy państwa. Autorki listów do peerelowskich instytucji niejednokrotnie opisywały swoje historie i pracę prokuratorów ${ }^{73}$. Mieszkająca w Bolkowie Janina G., matka trójki dzieci w wieku 2, 4 i 6 lat, którą we wrześniu 1956 r. porzucił mąż,

70 ODiZP TVP, KdsRiT „Polskie Radio i Telewizja”, BL, 1208/1/2, „Biuletyn Wewnętrzny” nr 409, luty 1968 , s. 1.

${ }^{71}$ AAN, KC PZPR, XXVII/5, Notatka o niektórych problemach związanych z alimentacją, k. 230, 233-335.

72 ODiZP TVP, KdsRiT „Polskie Radio i Telewizja”, BL, 1050/72, „Biuletyn Wewnętrzny” nr 309, grudzień 1966, s. 1.

73 AAN, KC PZPR, XXVII/3, Informacja o listach, które wpłynęły do Biura Listów i Inspekcji w lutym 1973, k. 79. 
dwa miesiące później złożyła pozew o alimenty w Sądzie Powiatowym w Jaworze. Zasądzonych kwot jednak nie można było ściągać, gdyż nie ustalono, gdzie przebywa ojciec. W tej sytuacji kobieta poprosiła o pomoc prokuraturę, która poleciła milicji ustalenie miejsca jego pobytu. Pozbawiona środków do życia kobieta wielokrotnie chodziła na posterunek milicji w Bolkowie i do prokuratury w Jaworze, prosząc o pomoc. W obu instytucjach radzono, aby sama ustaliła adres zamieszkania męża. Gdy w kwietniu 1957 r. znajomi poinformowali kobietę, że widzieli „męża wraz z kochanką w Jeleniej Górze", ta natychmiast powiadomiła milicję. Funkcjonariusze MO, zamiast bezzwłocznie zająć się sprawą, oczekiwali podania dokładnego adresu zamieszkania i miejsca pracy męża. Kobieta samotnie opiekująca się nie tylko trójką małych dzieci, ale i 68-letnią matką nie miała pieniędzy na opłacenie podróży, które umożliwiłyby ustalenie tych danych. Rozgoryczona i bezradna opisała swoje doświadczenia w liście do Polskiego Radia ${ }^{74}$.

W sytuacji złośliwego niewypełniania obowiązku alimentacyjnego samotne matki, mając prawomocny wyrok, mogły składać doniesienie do prokuratury. Niestety $w$ takich przypadkach prokuratury działały rutynowo. One także, nie mogąc ustalić adresu dłużnika, zawieszały postępowanie. Doświadczyła tego korespondentka z Brześcia Kujawskiego, której mąż nie płacił alimentów, doprowadzając „ją do nędzy”. Kobieta napisała skargę do Biura Listów Komitetu do spraw Radia i Telewizji, którego pracownicy od października 1964 do października 1966 r. czterokrotnie interweniowali w tej sprawie w prokuraturze we Włocławku. Odpowiedzi udzielono dopiero pod koniec października 1966 r. i wyjaśniono, że w styczniu 1965 r. postępowanie zostało zawieszone, bo dłużnik ukrywał się. Skargi kobiety spowodowały wspomniane interwencje Biura Listów w prokuraturze ${ }^{75}$. Dużą determinacją wykazała się Helena ze Stalowej Woli, która w maju 1967 r. złożyła w miejscowej prokuraturze wniosek o ustalenie adresu i spłatę alimentów przez ojca dziecka. Po trzech miesiącach została poinformowana o zawieszeniu postępowania, „gdyż poszukiwany ukrywał się". Kilka miesięcy później kobieta sama zdołała ustalić miejsce pobytu poszukiwanego, ale Komenda Miejska MO w Nisku powiadomiła kobietę, że dłużnika nie odnaleziono. Korespondentka opisywała, jak udawało się jej odnajdywać kolejne miejsca pobytu i pracy uchylającego się od płacenia alimentów. Zdeterminowana ustaliła także, że poszukiwany zmienił dowód osobisty, a nawet dostarczyła jego zdjęcia. Autorka prośby podawała, że dług sięgał ok. 15 tys. zł i nalegała, aby poszukiwania prowadzono w tajemnicy, by mężczyzna po raz kolejny nie wymknął się władzom ${ }^{76}$.

${ }^{74}$ ODiZP TVP, Komitet do spraw Radiofonii „Polskie Radio”, BL, 1050/20, t. 1, „Biuletyn” nr 39 z 1 VI 1957, k. 201.

75 ODiZP TVP, KdsRiT „Polskie Radio i Telewizja”, BL, 1050/72, „Biuletyn Wewnętrzny” nr 309, grudzień 1966, s. 5-6.

76 ODiZP TVP, KdsRiT „Polskie Radio i Telewizja”, BL, 1208/5/1, „Biuletyn Wewnętrzny” nr 466, październik 1968, s. 3-4. 
Poszukiwania uporczywie uchylających się od obowiązku alimentacyjnego prowadzone przez prokuratury i milicję trwały miesiące, a nawet lata. Potwierdza to przypadek Stefanii z Gdyni. Samotna matka skarżyła się, bo choć rozwiodła się w wrześniu $1958 \mathrm{r}$. i przyznano jej alimenty na dziecko, to niemal przez osiem lat nie odnaleziono ukrywającego się ojca. Na początku 1965 r. skierowała wniosek do prokuratury o ściganie go. Prokuratura poleciła milicji jego odszukanie. Nie udało się tego zrobić, a prokuratura - podobnie jak w wielu podobnych przypadkach zawiesiła postępowanie. W opinii korespondentki organy ścigania „poszły po najmniejszej linii oporu [sic] i zakpiły sobie" z tak poważnej dla niej sprawy. Podobnie jak inne samotne matki uważała za konieczne wydanie listu gończego. Prokuratura potwierdziła zawieszenie postępowania z powodu „nieujęcia podejrzanego”. Suma zaległych alimentów wynosiła 27 tys. zł, a kobieta zadłużała się, biorąc pożyczki na życie ${ }^{77}$. Podobną batalię prowadziła od $1958 \mathrm{r}$. Czesława zamieszkała w powiecie inowrocławskim. Sąd uznał, że ojciec złośliwie uchylał się od płacenia alimentów na syna. Jednak prokuratura w połowie września 1966 r. wyjaśniła, iż dłużnik nie został ujęty, bo się ukrywał i z tego powodu dochodzenie zawieszono ${ }^{78}$. Mieszkanka Pobiedzisk opisywała dziesięcioletnie zmagania o ustalenie ojcostwa i przyznanie alimentów, a następnie ich egzekucję. Korzystny dla niej wyrok zapadł w 1964 r., ale ojciec nie płacił zasądzonych kwot. Kolejny proces toczył się w 1967 r., jednak alimenty nadal nie były płacone. Komornik egzekucję umorzył „wobec niemożliwości ustalenia miejsca zamieszkania" dłużnika. Po złożeniu wniosku w prokuraturze o ściganie z powodu złośliwego uchylania się od obowiązku alimentacyjnego niestety nie udało się ustalić miejsca pobytu dłużnika. Ten był organistą i zatrudniał się w różnych parafiach, a to nie ułatwiało zadania. Ostatecznie prokurator zawiesił postępowanie karne i wydał postanowienie o tymczasowym aresztowaniu, co jednak również nie było łatwe z tych samych przyczyn. Finalnie dziesięcioletnie wysiłki matki nie zakończyły się pozytywnie ${ }^{79}$. Na podstawie informacji zawartych w analizowanych listach można skonstatować, że w prokuraturach decyzje o zawieszaniu postępowań karnych z powodu ukrywania się ojców zobowiązanych do płacenia alimentów podejmowano rutynowo. Prokuratorzy nie wykazywali się empatią wobec samotnych matek i ich dzieci. Podobnie efektywność milicyjnych poszukiwań była niewielka. Przebadana korespondencja zawiera wiele przykładów opieszałego i pobłażliwego procedowania przez organy ścigania spraw osób zobowiązanych do alimentacji ${ }^{80}$.

77 ODiZP TVP, KdsRiT „Polskie Radio i Telewizja”, BL, 1050/72, „Biuletyn Wewnętrzny” nr 309, grudzień 1966, s. 6-7.

${ }^{78}$ Ibidem, s. 15.

79 ODiZP TVP, KdsRiT „Polskie Radio i Telewizja”, BL, 1208/5/1, „Biuletyn Wewnętrzny” nr 466, październik 1968, s. 5.

80 ODiZP TVP, KdsRiT „Polskie Radio i Telewizja”, BL, 1050/72, „Biuletyn Wewnętrzny” nr 309, grudzień 1966, s. 7-10, 17-19; ibidem, 1208/5/1, „Biuletyn Wewnętrzny” nr 466, październik 1968, s. 6-8, 10-14. 
Nieefektywne działania aparatu państwowego podejmowane wobec ojców uchylających się przed obowiązkiem płacenia na swoje dzieci bulwersowały nie tylko bezradne matki, ale także osoby i instytucje, które chciały im pomagać. Nie potrafiono zrozumieć, dlaczego tak trudno ustalić miejsca pobytu poszukiwanych, choć obowiązują restrykcyjne przepisy meldunkowe ${ }^{81}$. Trudne to do zrozumienia tym bardziej, że ukrywający się byli zwykle młodymi mężczyznami, którzy chcąc podjąć pracę musieli gdzieś mieszkać i być zameldowani. Najpewniej jednak lokalna administracja nie zawsze dbała o terminowe dopełnienie obowiązku meldunkowego. $\mathrm{Z}$ tego powodu ustalenie adresu zameldowania dłużnika nie było łatwe, a gdy w końcu pozyskano tę informację, to wielokroć poszukiwany już tam nie mieszkał. Swoje wysiłki opisała m.in. samotna matka z Wrocławia, która sama chciała ustalić, gdzie przebywał unikający płacenia alimentów ojciec dziecka, aby o tym powiadomić sąd. O pomoc w tej sprawie zwróciła się też do Głównego Biura Adresowego, ale z miernymi efektami. Gdy jednak udało się już ustalić miejsce zamieszkania dłużnika, to ten ponownie znik ${ }^{82}$. W takich sytuacjach działania prokuratury były zawieszane lub co gorsza umarzane.

Konsekwencją próśb i skarg wysyłanych przez matki samotnie wychowujące dzieci do peerelowskich władz były nie tylko opisane interwencje w sądach i prokuraturach. Często efektem było udzielenie doraźnej pomocy kobietom, które nie mogły „dłużej pożyczać, aby nakarmić i ubrać dzieci”. Zajmowały się tym wydziały zdrowia i opieki społecznej oraz wydziały oświaty lokalnych rad narodowych, Polski Czerwony Krzyż, związki zawodowe ${ }^{83}$. Wsparcia finansowego udzielał powstały w 1958 r. Polski Komitet Pomocy Społecznej ${ }^{84}$, którego komisje alimentacyjne doraźnie wypłacały zaliczki ${ }^{85}$. W $1971 \mathrm{r}$. łączna kwota tych zaliczek wyniosła $1341700 \mathrm{zz}^{86}$. W praktyce była to bezzwrotna pomoc.

Obowiązujące regulacje prawne stanowiły, że prokuratura zobowiązana była ścigać dłużnika, który permanentnie unikał płacenia alimentów. Jeśli jednak co jakiś czas ojciec przekazywał nawet niewielkie sumy na poczet alimentów, to było to podstawą do umorzenia postępowania. Najpewniej świadomi tego dłużnicy stosowali

81 Dz.U. 1961, nr 33, poz. 164; ODiZP TVP, KdsRiT „Polskie Radio i Telewizja”, BL, 1050/72, „Biuletyn Wewnętrzny” nr 309, grudzień 1966 r., s. 2; ibidem, 1208/5/1, „Biuletyn Wewnętrzny” nr 466, październik 1968 r., s. 2.

82 ODiZP TVP, KdsRiT „Polskie Radio i Telewizja”, BL, 1050/72, „Biuletyn Wewnętrzny” nr 309, grudzień 1966, s. 8.

83 Ibidem, s. 1; AAN, KC PZPR, XXVII/5, Notatka o niektórych problemach związanych z alimentacją, k. 231-232.

${ }^{84}$ M. Andrzejewski, op. cit., s. 17; ODiZP TVP, Komitet do Spraw Radia i Telewizji „Polskie Radio i Telewizja”, BL, 1050/35, Notatka dla obywatela Ministra M. Rybickiego sporządzona stosownie do polecenia z dnia 19 III 1961, s. 4.

85 Z. Siwik, Rozmiary i dynamika spraw o niealimentacje w komisjach PKPS, „Problemy Rodziny” 1972, nr 5, s. 43.

${ }^{86}$ AAN, KC PZPR, XXVII/5, Notatka o niektórych problemach związanych z alimentacją, k. 232. 
taką taktykę, bo w ten sposób unikali więzienia. Potwierdza to przypadek opisany przez Czesławę z Jasła. Ojciec jej dwojga dzieci nie płacił alimentów, co spowodowało złożenie zażalenia do prokuratury. Ta sprawę umorzyła, uzasadniając, że niepłacenie alimentów przez trzy miesiące nie jest przestępstwem. Korespondentka co kilka miesięcy otrzymywała po 500, 600 zł, choć wyrokiem sądu miesięczne alimenty ustalono na 900 zł. Ponowna skarga złożona w prokuraturze także została umorzona, „bo on coś” przysyłał. W tym przypadku także i komornik nie kwapił się z egzekucją. Zwodził kobietę, że nie otrzymał wyroku sądowego. Jak się okazało, od wielu miesięcy wyrok miał, a i tak nie wystąpił do zakładu pracy dłużnika o potrącanie alimentów. Kobieta błagała o pomoc i spowodowanie, aby komornik, który przez dwa lata zwlekał z wysłaniem dokumentów do zakładu pracy ojca, w końcu to zrobił. Prezes sądu przyznał, że podlegający mu urzędnik egzekwował pieniądze od dłużnika, ale przekazywał innym jego wierzycielom, a pomijał alimenty ${ }^{87}$.

Instytucje badające opisane w listach sprawy alimentacyjne potwierdzały częste, nieuzasadnione zawieszanie i umarzanie poszukiwań dłużników przez organy ścigania. Przyznano, że w 1971 r. zrobiono tak z połową wniosków skierowanych do prokuratur. Opinia publiczna, a także niektóre instytucje zarzucały prokuraturze „brak operatywności i konsekwentnego działania”"8.

Udręczone samotne matki skarżyły się też na sposób postępowania MO. Powtarzały się opinie, że milicjanci działali po „kumotersku”, pozorując poszukiwania ojców niepłacących alimentów. Matka dwójki dzieci, mieszkająca w Piwnicznej, opisując w liście do radiowej „Fali 56” swoją walkę o alimenty informowała, że mąż nie stawiał się na rozprawy, a funkcjonariusze MO stwierdzali jego nieobecność w miejscu zamieszkania. Żona jednak twierdziła: „on zamieszkuje tam, gdzie mieszkał” wraz z kobietą, którą sobie „wziął” i jej dwójką dzieci. Korespondentka była zrozpaczona i bezradna, a nie wiedząc jak sobie poradzić, stawiała pytanie: „co mam zrobić: czy wytruć te [swoje - G.M.] dzieci, czy co?"89. Ten naganny, ale powszechny męski solidaryzm dotyczył nawet listonoszy. Otóż dłużnicy dogadywali się z listonoszami, którzy poświadczali, że nie mogli dostarczyć korespondencji z sądu, prokuratury, bo pod podanym adresem ten nie mieszka1 ${ }^{90}$. Korespondentki wielokrotnie informowały o podejmowanych na własną rękę próbach odnalezienia ojców ich dzieci. Trudności w ustaleniu miejsca pobytu ojca dzieci były jednym z głównych powodów utrudniających ściganie uchylających się od płacenia alimentów i ich egzekucję.

${ }^{87}$ ODiZP TVP, KdsRiT „Polskie Radio i Telewizja”, BL, 1208/1/2, „Biuletyn Wewnętrzny” nr 409, luty 1968, s. 5-6.

88 AAN, KC PZPR, XXVII/5, Notatka o niektórych problemach związanych z alimentacją, k. 236.

${ }^{89}$ ODiZP TVP, Komitet do spraw Radiofonii „Polskie Radio”, BL, 1050/20, t. 1, „Biuletyn” nr 39 z 1 VI 1957, k. 201-202.

90 ODiZP TVP, KdsRiT „Polskie Radio i Telewizja”, BL, 1050/35, Notatka w sprawie alimentów, I cz., Warszawa, 16 III 1961, s. 1-2. 
Narastanie kłopotów z egzekucją alimentów spowodowało podjęcie przez władze działań mających poprawić sytuację. Przykładowo, w 1966 r. ministrowie sprawiedliwości i spraw wewnętrznych wydali zarządzenie „w sprawie współdziałania organów Milicji Obywatelskiej z komornikiem przy ustalaniu miejsca zamieszkania i miejsca pracy dłużników w sądowym postępowaniu egzekucyjnym"91. W praktyce niewiele to zmieniło.

Dobitnym potwierdzeniem niskiej efektywności pracy prokuratur, a pośrednio i MO, do których wnioskowano o ściganie uchylających się od płacenia zasądzonych alimentów, są dane z $1971 \mathrm{r}$. W ciągu roku do prokuratur powiatowych wniesiono 22353 sprawy o niealimentacje. Konsekwencją śledztw i dochodzeń było sformułowanie 11557 aktów oskarżenia. W 3900 sprawach postępowanie zawieszono, 796 warunkowo umorzono, a 629 umorzono z braku dowodów winy. Nadto z braku znamion przestępstwa umorzono 5044, kolejne $122 \mathrm{z}$ powodu „znikomej szkodliwości społecznej czynu”, a 285 z innych powodów. Charakterystyczne, że spośród 11557 oskarżonych aż 5801 było wcześniej karanych, z tego $45 \%$ za przestępstwa alimentacyjne. Co ważne, wobec niepokojąco dużej liczby 3920 sprawców prokuratury zawiesiły postepowanie, bo podejrzani ukrywali się ${ }^{92}$. $\mathrm{Z}$ tego powodu tysiące matek i dzieci nie otrzymywały pieniędzy na życie. Było to kolejną przesłanką do stworzenia systemowych rozwiązań zapewniających wypłatę alimentów bez długotrwałego oczekiwania na efekty pracy aparatu ścigania.

\section{Zakłady pracy a egzekucja alimentów}

Zakłady pracy były zobowiązane do współdziałania w egzekwowaniu alimentów ${ }^{93}$. Z listów nadchodzących do władz wiadomo o przypadkach braku należytej uwagi, a czasami bagatelizowania spraw alimentacyjnych przez pracodawców. Wiadomo, że pracowników zobowiązanych do płacenia alimentów rejestrowały działy zatrudnienia oraz pracy i płac. Co charakterystyczne, działy płac w zakładach pracy skrupulatnie potrącały z uposażeń zatrudnionych najróżniejsze obciążenia, ale egzekucję alimentów wykonywały opieszale.

Poprawienie ściągalności długów, w tym alimentów przez zakłady pracy miały zapewnić przepisy wspomnianego już kodeksu postępowania cywilnego z 1964 r. ${ }^{94} \mathrm{~W}$ praktyce okazało się jednak, że spodziewanych rezultatów nie osiągnięto. Była to kolejna przesłanka do stworzenia instytucjonalnych rozwiązań

\footnotetext{
91 M.P. 1966, nr 31 poz. 166.

92 AAN, KC PZPR, XXVII/5, Notatka o niektórych problemach związanych z alimentacją, k. 230231.

93 J. Kruszewska, Współdziałanie zakładów pracy w egzekwowaniu obowiazzku alimentacyjnego, „Praca i Zabezpieczenie Społeczne” 1961, nr 7.

94 Dz.U. 1964, nr 43, poz. 296, art. 884.
} 
mających zapewnić wypłatę świadczeń alimentacyjnych osobie uprawnionej, gdy ich egzekucja od dłużnika napotyka na trudności ${ }^{95}$.

Jak wynika z listownych przekazów, praktykowane przez dłużników alimentacyjnych uciekanie i ukrywanie się niektórzy pracodawcy wręcz ułatwiali. Było już wspomniane, że prywatni pracodawcy wielokrotnie nie zawierali umów i nie ujawniali zarobków. Podmioty uspołecznione, państwowe i spółdzielcze, borykające się z brakami kadrowymi, zwykle nie domagały się opinii z poprzedniego miejsca pracy. Dawały nie tylko pracę, ale też nierzadko miejsce w hotelu robotniczym czy kwaterę. Zdarzało się, że taki pracownik meldował się na pobyt czasowy, gdy jednak orientował się, że ma milicję "na karku” uciekał i nadal był poszukiwany. $\mathrm{Ci}$,uciekinierzy” podejmujący pracę w innym miejscu fakt obowiązku alimentacyjnego zatajali, a w państwowych przedsiębiorstwach i instytucjach w większości przypadków przy zatrudnieniu o to nie pytano ${ }^{96}$.

W listach ze skargami formułowano różne postulaty mające usprawnić egzekucję alimentów także przez zakłady pracy. Zwracano uwagę na brak wpisu dzieci $\mathrm{w}$ dowodzie osobistym rodzica. W tym dokumencie nie było też adnotacji o nakazanym przez sąd obowiązku alimentacyjnym. Korespondencja zawiera przykłady źle rozumianej koleżeńskiej solidarności. Z tego powodu chroniący dłużników zapominali „o głodnych dzieciach i zaharowanej kobiecie”97. Rezultatem przebadania problematyki alimentacyjnej przeprowadzonej jesienią 1972 r. przez Biuro Listów i Inspekcji KC PZPR wspólnie z Prokuraturą Generalną, związkami zawodowymi, Ligą Kobiet i pracownikami innych urzędów centralnych zajmujących się obsługą korespondencji było kilka wniosków. Skrytykowano w nich m.in. wspomniany już brak przepisów nakazujących wpisywanie w dowodzie osobistym informacji o obowiązku alimentacyjnym ${ }^{98}$.

Badając trudności w ściąganiu alimentów przez zakłady pracy z wynagrodzeń wskazywano na ich przyczyny. Najogólniej wynikały one z biurokratycznej opieszałości. Obieg dokumentów trwał długo, co sprawiało, że nowo zatrudniony pracownik otrzymywał pierwsze wypłaty bez potrąceń. Zdarzało się, że po przepracowaniu dwóch, trzech, czterech miesięcy mężczyzna, przewidując, że pracodawca rozpocznie ściąganie alimentów, zwalniał się. Strategia częstej zmiany miejsca zatrudnienia przez zobowiązanych do alimentacji była wielokrotnie stosowana, co potwierdzano w czasie kontroli w zakładach pracy. Dostrzegano nawet pewną prawidłowość. Otóż, jeśli w nowym zakładzie pracy potrąceń alimentów dokonywano rygorystycznie i sprawnie, to był to zasadniczy powód szybkiego

\footnotetext{
95 Z. Wasilkowska, Prawna ochrona rodziny..., s. 158.

96 ODiZP TVP, KdsRiT „Polskie Radio i Telewizja”, BL, 1050/72, „Biuletyn Wewnętrzny” nr 309, grudzień 1966, s. 2.

97 ODiZP TVP, KdsRiT „Polskie Radio i Telewizja”, BL, 1208/5/1, „Biuletyn Wewnętrzny” nr 466, październik 1968, s. 2.

98 AAN, KC PZPR, XXVII/5, Notatka o niektórych problemach związanych z alimentacją, k. 236.
} 
odejścia pracownika. Formułowano wręcz pogląd, jakoby ściągalność alimentów była jednym z czynników wpływających na fluktuację kadr. Podawano przykłady mające potwierdzać takie twierdzenie. W Lubuskim Przedsiębiorstwie Budownictwa Przemysłowego w latach 1970-1971 spośród porzucających pracę aż 70\% było zobowiązanych do płacenia alimentów. Pracownicy Biura Listów i Inspekcji sprawdzający egzekucję alimentów przez pracodawców twierdzili: „Dłużników alimentacyjnych charakteryzuje [...] tendencja do podejmowania prac najniżej płatnych, a tym samym do świadomego obniżania własnych zarobków"99.

Należy jeszcze wspomnieć o pomocy udzielanej matkom samotnie wychowującym dzieci przez zakłady pracy. Formalnie zajmowały się tym rady zakładowe i związki zawodowe. Były to świadczenia doraźne określane jako „filantropijne”100. Nie poprawiały trwale materialnego statusu osób, które nie otrzymywały alimentów, była to jednak kolejna przesłanka dla wprowadzenia takich mechanizmów, które zapewniłyby stałe otrzymywanie kwot wynikających z wyroków sądów.

\section{Stosowanie kary więzienia za uchylanie się od obowiązku alimentacyjnego}

Przestępstwo, jakim było uchylanie się od płacenia alimentów, dawało podstawę do ścigania i karania. Wspomniano już, że obowiązujący w badanym okresie kodeks karny z 1932 r. przewidywał wobec osób umyślnie uchylających się od wypełniania obowiązku alimentacyjnego, wynikającego z prawomocnego wyroku sądowego, karę aresztu do lat trzech lub karę więzienia do lat trzech ${ }^{101}$. W praktyce, aby postawić przed sądem ojca niepłacącego zasądzonych alimentów, należało spełnić cztery warunki:

1. Trzeba było wykazać, że obowiązek alimentacyjny nie jest wypełniany.

2. Należało udowodnić, że z obowiązku alimentacyjnego nie wywiązuje się umyślnie.

3. Konieczne było udokumentowanie, że alimentów nie płaci nie tylko umyślnie, ale też złośliwie.

4. Niezbędnie dowieść, że z powodu niepłacenia alimentów dzieci i opiekunowie zostali doprowadzeni do nędzy lub konieczności korzystania z pomocy instytucji bądź innych osób.

Najtrudniej było wykazać owe złośliwe unikanie płacenia świadczenia. Jeśli nie zdołano udowodnić, że dłużnik z premedytacją uchylał się od płacenia na dzieci, to w praktyce zapewniało to mu bezkarność. Warto wspomnieć, że orzeczenia Sądu Najwyższego z lat pięćdziesiątych i sześćdziesiątych dawały m.in. nową

\footnotetext{
99 Ibidem, k. 234.

100 Ibidem, k. 233.

101 Dz.U. 1932, nr 60, poz. 571, art. 201.
} 
wykładnię pojęć „nędza”, „konieczność korzystania ze wsparcia” oraz możliwości zawieszenia wykonywania kary ${ }^{102}$.

W drugiej połowie lat pięćdziesiątych za uchylanie się od obowiązku alimentacyjnego sądy skazały: w 1957 r. - 5287 osób, w 1958 r. - 5470, a w 1959 r. $4206^{103}$. Jednak zasądzone kary nie były wysokie. Ministerstwo Sprawiedliwości w dokumencie z 1961 r. podawało, że wobec 50\% skazanych orzekano karę do 6 miesięcy pozbawienia wolności. Większość i tak nie trafiała do więzień, bowiem zawieszenie wykonania sięgało $70 \%$ orzeczonych karr $^{104}$. Dziesięć lat później, w 1971 r., sądy skazały 9931 osób. Wobec 3364 (32,8\%) orzeczono bezwzględną karę więzienia, w $6398(65,5 \%)$ zaś przypadkach wykonanie kary pozbawienia wolności warunkowo zawieszono. Wśród osób stających przed sądami sporą grupę stanowili recydywiści ${ }^{105}$.

Trudności z efektywnym wypełnianiem wspomnianego już artykułu 201 kodeksu karnego z 1932 r. były sygnalizowane w listach przez samotne matki, ale także przez publicystów i organizacje społeczne ${ }^{106}$. Nadzieję na zmianę sytuacji oraz szybsze i skuteczne pociąganie do odpowiedzialności karnej wobec uchylających się od płacenia alimentów dawało podjęcie na początku lat sześćdziesiątych prac nad nowym kodeksem karnym ${ }^{107}$. Opracowując ten zbiór przepisów, starano się usunąć niedoskonałości artykułu 201. W projekcie wprowadzono pojęcie uporczywego uchylania się od płacenia alimentów jako przesłankę do uznania tego jako przestępstwo. Ważną zmianą była możliwość złożenia wniosku o ściganie dłużnika przez organ opieki społecznej lub organizację społeczną ${ }^{108}$. Przypomnijmy - kodeks karny z 1932 r. przewidywał ściganie osoby uchylającej się od płacenia alimentów tylko na wniosek osoby pokrzywdzonej ${ }^{109}$.

Nowy kodeks karny, uchwalony 19 kwietnia 1969 r., wobec uporczywie uchylających się od wykonania obowiązku alimentacyjnego przewidywał karę

102 Więcej zob.: M. Siewierski, Kodeks karny i prawo o wykroczeniach. Komentarz, Warszawa 1958, s. 268-272; M. Siewierski, Kodeks karny i prawo o wykroczeniach. Komentarz, Warszawa 1965, s. 237-240; W. Wanatowska, Ochrona prawna roszczeń alimentacyjnych, „Studia Prawno-Ekonomiczne" 18, 1977, s. 75-76.

103 ODiZP TVP, KdsRiT „Polskie Radio i Telewizja”, BL, 1050/35, Notatka dla obywatela Ministra M. Rybickiego sporządzona stosownie do polecenia z dnia 19 III 1961, s. 6.

${ }^{104}$ Ibidem.

105 AAN, KC PZPR, XXVII/5, Notatka o niektórych problemach związanych z alimentacją, k. 231.

106 ODiZP TVP, KdsRiT „Polskie Radio i Telewizja”, BL, 1050/72, „Biuletyn Wewnętrzny” nr 309, grudzień 1966, s. 1.

107 ODiZP TVP, KdsRiT „Polskie Radio i Telewizja”, BL, 1050/42, Serwis Biura Listów nr 80, Umarł król - niech żyje król (podzwonne 201 art. k.k.), Warszawa, maj 1963, s. 1-2, 9-10.

108 Spis organizacji społecznych uprawnionych do wytaczania spraw o alimenty na rzecz swoich członków zamieszczono w Zarządzeniu Ministra Sprawiedliwości z 13 lipca 1965 r. (M.P. 1965, nr 37, poz. 213), które zostało zmienione 9 listopada 1968 r. (M.P. 1968, nr 50, poz. 349).

109 Dz.U. 1932, nr 60, poz. 571, art. 201; ODiZP TVP, KdsRiT „Polskie Radio i Telewizja”, BL, 1208/5/1, „Biuletyn Wewnętrzny” nr 466, październik 1968, s. 1. 
więzienia do lat trzech ${ }^{110}$. Wykładnię artykułu 186 zawarto w komentarzu wydanym w $1971 \mathrm{r}^{111}$

W badanym okresie liczba osób skazanych za unikanie płacenia alimentów rosła (tab. 2).

Tabela 2. Skazani za przestępstwo niealimentacji w latach 1955-1974

\begin{tabular}{|l|l|l|l|l|l|}
\hline \multicolumn{1}{|c|}{ Rok } & $\mathbf{1 9 5 5}$ & $\mathbf{1 9 6 0}$ & $\mathbf{1 9 6 5}$ & $\mathbf{1 9 7 0}$ & $\mathbf{1 9 7 4}$ \\
\hline Liczba skazanych ogółem & 4748 & 4999 & 7303 & 9349 & 7598 \\
\hline Liczba skazanych mężczyzn & 4729 & 4971 & 7208 & 9189 & 7400 \\
\hline
\end{tabular}

Źródło: Z. Siwik, Statystyczna ocena przestępczości niealimentacyjnej w latach 1954-1974, w: Wybrane zagadnienia patologii rodziny, red. M. Jarosz, Warszawa 1976, s. 54, 56.

Spadek liczby skazanych w 1974 r. wynikał najpewniej z amnestii ogłoszonej w związku z trzydziestoleciem Polski Ludowej ${ }^{112}$. Podobne były konsekwencje wcześniejszych amnestii z lat 1956, 1964 i $1969^{113}$. Zebrane w tabeli 2 dane świadczą, że niealimentacja była przestępstwem popełnianym w absolutnej większości przez mężczyzn. W okresie 1954-1974 za to przestępstwo skazano 133960 mężczyzn i 1950 kobiet, co w ujęciu procentowym stanowiło odpowiednio 98,5\% i $1,5 \%{ }^{114}$. Problem był poważny i wymagał pilnego wypracowania skutecznych sposobów pomocy rodzicom samotnie wychowującym dzieci.

Z powyższych ustaleń wiadomo, że wiele konkretnych przypadków ojców „niepłacących", opisywanych w listach, kończyło się wcześniej czy później procesem i wyrokiem skazującym ich na karę pozbawienia wolności. Było już wzmiankowane, że po wydaniu wyroku przez sąd wielu z nich, chcąc utrudnić egzekucję alimentów, zmieniało miejsce zamieszkania i pracę. Przykładowo, ojciec dzieci Wiesławy z Ełku przebywał w Lublinie, a następnie wyjechał do Malborka. Tam utrzymywał się z pracy doraźnej, aby „starczyło na życie i rozrywki”. Chcąc utrudnić „pościg komornika”, podobnie jak wielu innych, często zmieniał miejsce pracy i zamieszkania. Metoda była skuteczna, bo komornik w Malborku poinformował, że nie jest w stanie egzekwować alimentów. Urzędnik poradził kobiecie zwrócenie się do prokuratury, aby ta ścigała dłużnika i postawiła go przed sądem. Samotna matka skorzystała z tej porady. Dłużnika w końcu skazano, ale alimentów i tak nie zapłacił, a było tego ponad 50 tys. $z^{115}$.

110 Dz.U. 1969, nr 13, poz. 94, art. 186.

111 J. Bafia, K. Miodulski, M. Siewierski, Kodeks karny. Komentarz, Warszawa 1971, s. 426-429.

112 Dz.U. 1974, nr 27, poz. 159.

113 Z. Siwik, Statystyczna ocena przestępczości niealimentacyjnej w latach 1954-1974, w: Wybrane zagadnienia patologii rodziny..., s. 54 .

114 Ibidem, s. 62.

115 ODiZP TVP, KdsRiT „Polskie Radio i Telewizja”, BL, 1207/3, „Biuletyn Wewnętrzny” nr 315, luty 1967, s. 12. 
W analizowanych listach samotne matki podnosiły kwestię długotrwałego niewywiązywania się ojców z obowiązku alimentacyjnego. Pani Kazimiera z Bielawy skarżyła się, że przyznanych przez sąd w sierpniu 1962 r. alimentów nie otrzymywała od grudnia tegoż roku. W maju 1965 r. wniosła sprawę do sądu w Dzierżoniowie, a ten za złośliwe uchylanie się od płacenia alimentów skazał ojca na karę 18 miesięcy więzienia w zawieszeniu na cztery lata. Wyrok nic nie zmienił. Skazany nadal nie płacił, a sąd kolejne postępowanie zawiesił po tym, jak MO stwierdziła w piśmie, że nie ustalono miejsca pobytu skazanego. Dług sięgał 30 tys. zł. Dramatyczne położenie samotnej matki oddaje fragment listu: „zima idzie, dzieci gołe, nie ma za co kupić"116.

$\mathrm{Z}$ wielu listów dotyczących alimentów dowiadujemy się, że skazanie przez sąd dłużnika uchylającego się od płacenia alimentów, a nawet osadzenie go w zakładzie karnym nie zmieniało sytuacji materialnej matki, bo nadal pozostawała bez wystarczających środków na utrzymanie dziecka lub dzieci ${ }^{117}$. W związku z takimi przypadkami formułowano postulaty mające zmusić skazanych do pracy, a zarobione pieniądze przeznaczyć na alimenty. Prezes Sądu Powiatowego w Pasłęku proponował tworzyć „obozy pracy dla systematycznie uchylających się od płacenia alimentów"118. Podobne rozwiązanie przedstawił prezes Sądu Powiatowego w Szczytnie. Nie bez racji argumentował, że zamykanie w więzieniu skazanych z artykułu 201 kodeksu karnego nie rozwiązuje problemu. Nawet gdy któryś z nich trafi do „Ośrodka Pracy”, to komornik otrzyma 53 zł miesięcznie. Tymczasem zobowiązania wielu skazanych za notoryczne niepłacenie alimentów szły w tysiące. Sędzia zgłosił propozycję, aby „dla takich nierobów i notorycznych pijaków” stworzyć „Ośrodek dla spraw «A»”. Osadzony tam dłużnik miał tak długo pracować, aż spłacił zaległe alimenty. Wielokrotnie bowiem nawet kilkakrotne osadzanie $\mathrm{w}$ więzieniu nic nie zmieniało. Wyrodny ojciec po odsiedzeniu kary nadal nie płacił, a matka i dzieci pozostawały bez środków do życia ${ }^{119}$.

Listy świadczą o upartym dążeniu samotnych matek do egzekucji zasądzonych alimentów. Kobiety miały nadzieję, że osadzenie w więzieniu niepłacącego alimentów ojca zmieni sytuację. Przede wszystkim oczekiwały podjęcia pracy w zakładzie karnym, co mogło umożliwić regulowanie choćby bieżących zobowiązań na dzieci. Zwykle jednak osadzeni nie kwapili się do tego. Dlatego

116 ODiZP TVP, KdsRiT „Polskie Radio i Telewizja”, BL, 1050/72, „Biuletyn Wewnętrzny” nr 309, grudzień 1966, s. 5.

117 ODiZP TVP, KdsRiT „Polskie Radio i Telewizja”, BL, 1050/35, Notatka w sprawie alimentów, I cz., Warszawa, 16 III 1961, s. 2; AAN, KC PZPR, XXVII/3, Informacja o listach, które wpłynęły do Biura Listów i Inspekcji w lutym 1973, k. 78.

118 Zdając sobie sprawę, że taka nazwa kojarzy się z okupację hitlerowską, proponowano przykładowo, aby był to Ośrodek Pracy Przymusowej, ODiZP TVP, KdsRiT „Polskie Radio i Telewizja”, BL, 1050/35, Notatka w sprawie alimentów, I cz., Warszawa, 16 III 1961, s. 6.

119 Ibidem, s. 6-7. 
minister sprawiedliwości w zarządzeniu wydanym 25 sierpnia 1961 r. nakazywał, aby osoby skazane z artykułu 201 kk zatrudniać w pierwszej kolejności. Nawet gdy więzionego dłużnika zatrudniono, to często jako recydywista dostawał nisko płatną pracę, a rodzina otrzymywała tylko $20 \%$ jego poborów. W przypadku wykonywania lepiej płatnej pracy zarządzeniem Dyrektora Centralnego Zarządu Więziennictwa z 15 listopada 1961 r. dzieciom można było przekazać jedynie $25 \%$ zarobionych pieniędzy. Niestety kwota ta była pomniejszona o koszty egzekucji, które pobierano w pierwszej kolejności ${ }^{120}$. W konsekwencji tych procedur najbardziej potrzebujący - dzieci i ich matki - nie otrzymywali sum, które zostały zasądzone.

Było już wzmiankowane, że wielu osadzonych w zakładach karnych zdecydowanie odmawiało podjęcia pracy. W wielu listach samotnych matek powracało więc pytanie, dlaczego nie można zmusić ich do pracy. Korespondentka z Poznania, matka trojga dzieci, których ojciec odbywał karę w zakładzie karnym w Rawiczu pytała: „dlaczego w więzieniu mój były mąż nie może pracować?” Kobieta znajdowała się trudnej sytuacji, bo choć sąd przyznał alimenty po $400 \mathrm{zł}$ miesięcznie na dziecko, to od więzionego byłego męża taką sumę otrzymała przez pół roku. Kwota była tak mała, że kobieta musiała szukać pomocy. Po interwencji uzyskała doraźne wsparcie z Polskiego Komitetu Pomocy Społecznej, co jednak nie rozwiązywało problemu. Mieszkanka jednej z wielkopolskich wsi w liście do Polskiego Radia domagała się, aby ojciec jej dziecka, mający zawód, nie odbywał „bezczynnie” kary ${ }^{121}$. Podobne oczekiwania miała Marianna ze Zduńskiej Woli. Ojciec jej córki był recydywistą, a otrzymywane z więzienia w Strzelcach Opolskich kwoty na poczet alimentów były bardzo niskie. Korespondentka domagała się, aby więźniowi dać lepiej płatną pracę lub przenieść do Ośrodka Pracy Więźniów. Po interwencji władze penitencjarne wyjaśniły, że skazany był wielokrotnie karany dyscyplinarnie i dlatego musiano przenieść go z OPW Głogów do więzienia w Strzelcach Opolskich ${ }^{122}$. Korespondentka z Gniezna, która otrzymała z sądu wyrok o przyznaniu miesięcznych alimentów na córkę Elę w kwocie 400 zł skarżyła się, że dług wynosi już 16878 zł. Ponadto sąd nałożył obowiązek alimentacyjny wobec jej córki Iwony (600 zł) i syna Dariusza (300 zł). Tutaj dług wynosił 18950 zł. Ojciec dzieci trafił do więzienia w Gnieźnie na trzy lata. Matka domagała się, aby został przeniesiony „do pracy na Śląsku dla uzyskania lepszego wynagrodzenia” 123 . Długi tego i wielu innych skazanych na karę więzienia z powodu niepłacenia alimentów na dzieci były tak duże, że żadna praca w zakładzie karnym nie dawała możliwości

120 ODiZP TVP, KdsRiT „Polskie Radio i Telewizja”, BL, 1207/3, „Biuletyn Wewnętrzny” nr 315, luty 1967 , s. 1.

121 Ibidem, s. 2-3.

122 Ibidem, s. 4-5.

${ }^{123}$ Ibidem, s. 8-9. 
regulowania bieżących zobowiązań alimentacyjnych. W konsekwencji zaległości były coraz większe.

Listy zawierają świadectwa innych zachowań mężczyzn notorycznie unikających płacenia alimentów. Zdarzało się, że deklarowali oni gotowość świadczeń na dzieci, jednak na wiele sposobów zwlekali z wywiązywaniem się z tego obowiązku. Ostatecznie po wielu miesiącach, nierzadko latach w końcu trafiali do zakładów karnych. Nawet jeśli tam pracowali, to nie płacili alimentów. Skarżyła się na to samotna matka z Olkusza. Ojciec dwóch jej córek odbywał karę więzienia w Nowej Hucie, ale administracja tego ośrodka karnego nie przesyłała pieniędzy. Zrozpaczona kobieta w liście informowała: „Do obecnej chwili nie otrzymałam ani jednego grosza"124. Podobna była sytuacja Anny z Radzynia Chełmińskiego. W grudniu 1965 r. sąd orzekł o obowiązku alimentacyjnym wobec dzieci. Uchylającego się od płacenia ojca milicja zatrzymała w czerwcu 1966 r., a sąd skazał go na karę 10 miesięcy więzienia. Jednak do listopada kobieta nie otrzymała „ani grosza”, a dług urósł do 12 tys. zł. Odpowiadając na interwencję Polskiego Radia naczelnik więzienia w Chełmie wyjaśnił, że skazany nie miał pieniędzy, bo w poprzednich więzieniach nie pracował ${ }^{125}$. W liście z lipca 1966 r. znajdujemy historię zmagań o alimenty mieszkanki Białegostoku. Mąż został zobowiązany do płacenia alimentów na dwoje dzieci. Początkowo płacił nieregularnie niewielkie sumy. Kobieta wiedziała, że pracował dorywczo na prywatnych budowach, gdzie podobno zarabiał ok. 3 tys. miesięcznie. Ostatecznie zaprzestał płacenia alimentów. $Z$ tego powodu trafił do więzienia na osiem miesięcy. Jednak w więzieniu w Barczewie nie pracował. Kobieta interweniowała, ale poinformowano ją, że więzień jest chory i pracować fizycznie nie może. Informacja ta nie była dla niej wiarygodna. Jej zdaniem mąż był zdrowy, a w zakładzie karnym miał warunki wczasowo-sanatoryjne ${ }^{126}$. Inna korespondentka, której mąż od lat zalegał z płaceniem alimentów, za co w końcu trafił do więzienia twierdziła, że dla niego nie był to szczególny dyskomfort. Podobno dłużnik chwalił sobie więzienne wyżywienie, opiekę medyczną „i na zimę chętnie poszedłby do niego znowu". W związku $\mathrm{z}$ tym samotna matka pozbawiona środków do życia pytała: „Czy [...] nie stwarzamy zbyt cieplarnianych warunków więźniom z zakładów karnych?”"127.

Było już wspomniane, że zobowiązani do alimentacji ojcowie rozmyślnie płacili nieregularnie i niewielkie kwoty. Stosując z premedytacją taką taktykę, nie mogli być uznani za uporczywie uchylających się od nałożonego decyzją sądu obowiązku alimentacyjnego. W takich przypadkach samotne matki były bezradne, bowiem

124 Ibidem, s. 5-6.

125 Ibidem, s. 9-10.

126 Ibidem, s. 10-11.

127 AAN, KC PZPR, XXVII/3, Informacja o listach, które wpłynęły do Biura Listów i Inspekcji w lutym 1973, k. 79. 
wymiar sprawiedliwości zawieszał lub umarzał postępowanie. Dzieci i matki nie otrzymywały kwot określonych wyrokiem sądu a znacznie niższe ${ }^{128}$. Zadłużenie rosło, a ojciec długo pozostawał bezkarny.

Dochodziło i do takich sytuacji, że w trakcie odbywania kary więzień zbiegł. Tak zrobił przebywający w OPW Szeroka koło Rybnika w lipcu 1967 r. Stanisław T. Przez wiele miesięcy milicja nie odnalazła zbiega. W tej sytuacji komornik, nie mogąc ściągać alimentów, czuł się usprawiedliwiony ${ }^{129}$.

Wspomniana już praktyka pierwszeństwa pobierania przez komorników kwot $\mathrm{z}$ tytułu postępowania egzekucyjnego powodowała, że więźniowie skazani za uchylanie się od płacenia alimentów pracowali w pierwszym rzędzie na komorników. Było już wzmiankowane, że komornicy opieszale, a wielokroć pozornie działali, aby ściągnąć z dłużników zaległe alimenty. Gdy jednak taki uporczywie unikający płacenia na swoje dzieci w końcu został osadzony w więzieniu, to komornicy skutecznie występowali do zakładów karnych o egzekucje długów. Dla dzieci i ich matek pieniędzy już nie starczało. Potwierdzał to choćby prezes Sądu Powiatowego w Częstochowie. Podlegający mu komornik od stycznia 1965 r. bezskutecznie prowadził egzekucję alimentów. Gdy dłużnika w grudniu 1965 r. uwięziono w Wołowie, to po kilku miesiącach, w lipcu 1966 r., komornik otrzymał 21 zł, a we wrześniu 41 zł. Uzyskane pieniądze zaliczył na koszt postępowania egzekucyjnego, a w piśmie do naczelnika więzienia domagał się wyjaśnień, dlaczego otrzymał tak małe kwoty ${ }^{130}$. Praktyka potrącania kosztów egzekucji od wierzycieli, a nie od dłużników wywoływała oburzenie ${ }^{131}$. Komornicy obciążali samotne matki nawet opłatami pocztowymi w związku z prowadzonymi egzekucjami ${ }^{132}$. Na początku dekady gierkowskiej nic się nie zmieniło. Rodziny otrzymywały niewielkie kwoty należnych alimentów od odbywających kary więzienia. W notatce przygotowanej przez Biuro Listów i Inspekcji KC PZPR podawano wymowny przykład. Od osadzonego w więzieniu za niepłacenie alimentów w ciągu 18 miesięcy przekazano 72 zł, a miesięczna kwota alimentów miała wynosić 600 zł. W tej sytuacji nie mogą dziwić zaległości, które urosły do 40 tys. zł ${ }^{133}$. Według danych na dzień 30 czerwca 1972 r. przeciętna miesięczna rata alimentacyjna przekazywana z zakładów karnych na poczet alimentów wynosiła $327 \mathrm{zł}$. Jednak z tej sumy około 1/3 zatrzymywali

128 Ibidem, k. 79.

129 ODiZP TVP, KdsRiT „Polskie Radio i Telewizja”, BL, 1208/5/1, „Biuletyn Wewnętrzny” nr 466, październik 1968, s. 6-7.

130 ODiZP TVP, KdsRiT „Polskie Radio i Telewizja”, BL, 1207/3, „Biuletyn Wewnętrzny” nr 315, luty 1967 , s. 3.

131 ODiZP TVP, KdsRiT „Polskie Radio i Telewizja”, BL, 1208/1/2, „Biuletyn Wewnętrzny” nr 409, luty 1968, s. 2.

132 Ibidem, s. 7.

133 AAN, KC PZPR, XXVII/5, Notatka o niektórych problemach związanych z alimentacją, k. 233. 
komornicy tytułem kosztów egzekucji ${ }^{134}$. W całym badanym okresie komornicy dbali przede wszystkim o swoje interesy.

Jak wspomniano, zamknięcie w więzieniu ojców niepłacących alimentów nic nie zmieniało w sytuacji samotnych matek. Mieszkanka Poznania skarżyła się, że ojciec dzieci za złośliwe uchylanie się od płacenia alimentów został osadzony w Rawiczu. W czasie odbywania kary nadal nie płacił. Miał siedzieć rok, ale został wcześniej zwolniony. Tymczasem dług urósł do 70 tys. $z^{135}$. Podobny przypadek opisała Stanisława z powiatu Brzozów. Jej mąż w 1966 r. został skazany na sześć miesięcy więzienia. Po odbyciu kary wciąż nie płacił alimentów i na początku lutego 1967 r. ponownie trafił do zakładu karnego. Gdy po odbyciu kary wyszedł z więzienia, konsekwentnie unikał płacenia alimentów, porzucił gospodarstwo, ukrywał się, nie stawiał się na wezwania sądu ${ }^{136}$. Takich historii było wiele.

W niektórych listach opisywano przypadki nękania matek przez ojców unikających płacenia alimentów. Doświadczyła tego Stefania ze Szczecina, matka dwójki dzieci. W swoim liście skarżyła się na byłego męża, który przez wiele lat nie płacił alimentów, za co w końcu trafił do więzienia. Korespondentka opisała swoje zmagania w sądzie o podwyższenie alimentów. Po korzystnym wyroku pojawił się powszechnie sygnalizowany w korespondencji samotnych matek problem $\mathrm{z}$ wyegzekwowaniem należności. Podobnie jak w wielu innych przypadkach prokuratura i milicja nie mogły dłużnika odnaleźć. W tym czasie ten telefonicznie co kilka dni nękał kobietę. Ironicznie pytał o jej sytuację finansową i „w najgorszy sposób” jej ubliżał. W swym liście dręczona kobieta tak opisała swoją sytuację: „Wydatki z roku na rok wzrastają, a ja naprawdę ciągnę resztkami sił"137.

Zostało już ustalone, że wśród osób skazanych za różne przestępstwa na karę bezwzględnego pozbawienia wolności spora grupa miała obowiązek płacenia alimentów. W połowie 1972 r. dotyczyło to 11933 osób, co stanowiło 12\% ogólnej liczby osadzonych w zakładach karnych. Pracowała większość - 11024 osoby ${ }^{138}$.

Niska ściągalność zobowiązań alimentacyjnych nawet od osadzonych w zakładach karnych była kolejną przesłanką do stworzenia instytucjonalnych rozwiązań gwarantujących samotnym matkom regularne otrzymywanie alimentów.

${ }^{134}$ Ibidem, k. 235; AAN, KC PZPR, XXVII/3, Informacja o listach, które wpłynęły do Biura Listów i Inspekcji w lutym 1973, k. 78.

135 ODiZP TVP, KdsRiT „Polskie Radio i Telewizja”, BL, 1207/3, „Biuletyn Wewnętrzny” nr 315, luty 1967 , s. 10.

136 ODiZP TVP, KdsRiT „Polskie Radio i Telewizja”, BL, 1231/3, „Biuletyn Wewnętrzny” nr 9 (607), kwiecień 1972, O egzekucji alimentów, cz. 1, oprac. red. B. Kwiecień, s. 9.

137 ODiZP TVP, KdsRiT „Polskie Radio i Telewizja”, BL, 1208/5/1, „Biuletyn Wewnętrzny” nr 466, październik 1968, s. 15-16.

138 AAN, KC PZPR, XXVII/5, Notatka o niektórych problemach związanych z alimentacją, k. 234235. 


\section{Podsumowanie. Jak doszło do ustanowienia funduszu alimentacyjnego?}

Narastający problem, wynikający z potrzeby efektywnej egzekucji alimentów, skłaniał do szukania działań naprawczych. Stale domagano się, aby milicja i prokuratury skuteczniej ścigały dłużników celowo uchylających się od płacenia alimentów. W związku ze stosowaną przez dłużników strategią permanentnego zmieniania miejsca pracy i zamieszkania postulowano, aby po ustaleniu miejsca pobytu stosować areszt tymczasowy. Wnioskowano też o wprowadzenie obowiązku wpisywania w dowodzie osobistym posiadanych dzieci i rozważenie propozycji zamieszczania $\mathrm{w}$ dowodzie osobistym adnotacji o orzeczonym przez sąd obowiązku alimentacyjnym. W takiej sytuacji zakłady pracy mogłyby potrącać z poborów dłużników zasądzone alimenty, nie czekając na wniosek komornika. Zwracano też uwagę na potrzebę nagłośnienia problemu unikania płacenia alimentów w prasie, audycjach radiowych i telewizyjnych ${ }^{139}$.

Należy podkreślić, że w Polsce po II wojnie światowej powoli rosła społeczna świadomość dramatycznych konsekwencji unikania płacenia alimentów przez ojców. Wiele osób znało przypadki samotnych matek, które nie miały środków na zaspokojenie podstawowych potrzeb dzieci. Niewątpliwie opinie instytucji zajmujących się sprawami alimentacyjnymi miały wpływ na ewolucję polityki władz partyjno-państwowych. Nie można było dłużej bagatelizować trudności z egzekucją orzeczeń sądów w sprawach o alimenty, tym bardziej że ich liczba stale rosła.

Do władz PRL docierały informacje o samotnych matkach zabiegających o uzyskanie alimentów, a zwłaszcza ich egzekucję. Skargi i prośby napływające do centralnych instytucji i urzędów zawierały opisy codziennych zmagań w sytuacji niedostatku lub braku pieniędzy na podstawowe wydatki. $Z$ tego powodu niepełne rodziny nie mogły kupić żywności, ubrań, lekarstw. Żyjące w niedostatku dzieci miały ograniczone możliwości rozwoju, tak w wymiarze fizycznym, jak i intelektualnym. W badanym okresie rosło przekonanie o niebezpiecznych konsekwencjach zupełnego braku lub daleko niewystarczającej pomocy udzielanej matkom samotnie wychowującym dzieci. Kwestią niebagatelną była rosnąca wśród społeczeństwa świadomość problemów, z którymi borykały się niezamężne matki i ich dzieci. Nadto start życiowy dzieci wychowywanych bez ojca był z pewnością trudniejszy ${ }^{140}$.

O udrękach samotnego macierzyństwa pisano nie tylko w listach. Szukając pomocy, pozbawione środków do życia samotne matki opowiadały o swoich

\footnotetext{
139 ODiZP TVP, KdsRiT „Polskie Radio i Telewizja”, BL, 1208/5/1, „Biuletyn Wewnętrzny” nr 466, październik 1968, s. 2-3.

140 B. Łobodzińska, Rodzina w Polsce, Warszawa 1974, s. 157-158.
} 
dramatach w pokojach przyjęć komitetów PZPR, urzędach rad narodowych, siedzibach związków zawodowych. Efektem tych osobistych interwencji, podobnie jak próśb i skarg zgłaszanych listownie, było udzielenie doraźnej pomocy, choć, jak wspominano, takie wsparcie miało niestety charakter krótkookresowy. Zostało też ustalone, że w analizowanym okresie rosła liczba osób nieotrzymujących alimentów, którym wypłacano zapomogi. Od końca lat pięćdziesiątych najważniejszą rolę w tych działaniach pełnił PKPS, rady narodowe, zakłady pracy. Trzeba jednak mocno podkreślić, że taka pomoc tylko chwilowo łagodziła problem.

Państwowi i partyjni urzędnicy samokrytycznie przyznali, że nie ma jednej instytucji sprawującej nadzór nad całością polityki alimentacyjnej. Nie dysponowano danymi o liczbie i wielkości doraźnych świadczeń wypłacanych osobom, które znalazły się $\mathrm{w}$ trudnym położeniu materialnym z powodu nieotrzymywania przyznanych alimentów. Trzeba jednak przyznać, że w analizowanym okresie coraz częściej dostrzegano konieczność pomocy niepełnym rodzinom. Było już wspomniane o wsparciu udzielanym przez wydziały zdrowia i opieki społecznej oraz wydziały oświaty terenowych rad narodowych, które wypłacały stypendia, fundowały korzystanie ze stołówek, internatów, wczasów, kolonii. Agendy PKPS i PCK, związki zawodowe udzielały zapomóg, opłacały lub dofinansowywały żłobki, przedszkola, kolonie i obozy dla dzieci i młodzieży ${ }^{141}$. Była to jednak pomoc doraźna, zwykle przyznawana po interwencji samotnej matki lub instytucji występującej w jej imieniu. Sytuacja wymuszała stworzenie rozwiązań systemowych gwarantujących wypłatę alimentów w przypadkach nieregulowania tych zobowiązań przez ojców. W ostatnich latach badanego okresu formułowano w listach do peerelowskich instytucji powtarzający się postulat utworzenia instytucji państwowej, której zadaniem byłoby wypłacanie zasądzonych alimentów w sytuacjach, gdy ojciec dłużnik nie płaci ${ }^{142}$. Samotne matki pisały rozpaczliwe listy o swojej bezsilności i bezradności wobec problemu. Skarżyły się na brak wsparcia i empatii państwowych urzędników - sędziów, prokuratorów, komorników ${ }^{143}$.

Przedstawione ustalenia świadczą, jak nieskuteczne było ściąganie alimentów. Działo się tak od chwili uchwalenia stosownych przepisów jeszcze przed II wojną światową. W ciągu trzydziestu lat Polska „ludowa” nie potrafiła się z tym uporać. Warto w tym miejscu wspomnieć, że problemy z wykonywaniem orzeczeń alimentacyjnych występowały we wszystkich państwach, w których istniał obowiązek łożenia na małoletnie dzieci.

141 AAN, KC PZPR, XXVII/5, Notatka o niektórych problemach związanych z alimentacją, k. 231232.

142 Ibidem, k. 233-234.

143 AAN, KC PZPR, XXVII/3, Informacja o listach, które wpłynęły do Biura Listów i Inspekcji w lutym 1973, k. 78. 
Przedstawione trudności w egzekucji alimentów wymuszały stworzenie lepszych i efektywniejszych sposobów ochrony bytu dzieci i samotnych matek. Projekt instytucjonalnych rozwiązań gwarantujących wypłacanie zasądzonych alimentów w przypadkach uporczywego uchylania się od tego obowiązku ojców pojawił się w 1969 r. Propozycja wywołała ożywioną dyskusję w gabinetach urzędników i na łamach prasy ${ }^{144}$. Pomysł przejęcia przez skarb państwa wypłaty alimentów, w przypadku gdy ojciec uchylał się od świadczeń, przedstawiła „Przyjaciółka”145.

Nowa ekipa, która przejęła władzę po robotniczych protestach w grudniu 1970 r., ambitnie zaplanowała modernizację państwa. Ważnym elementem miała być nowoczesna polityka społeczna. Określając jej cele i sposoby realizacji, korzystano ze wsparcia ekspertów ${ }^{146}$. Najpewniej jedną z przesłanek nowej polityki społecznej był „alarm demograficzny” ${ }^{147}$. W tym czasie w Polsce, a i w innych państwach bloku wschodniego, nastąpił spadek liczby urodzin ${ }^{148}$. O nowej polityce społecznej zdecydowano na VI Zjeździe PZPR ${ }^{149}$. Kwestię prowadzenia aktywnej polityki ludnościowej poruszono na posiedzeniu plenarnym KC PZPR w listopadzie 1972 r. ${ }^{150} \mathrm{O}$ zadaniach polityki społecznej dyskutowano podczas I Krajowej Konferencji PZPR w październiku 1973 r. i na kolejnych posiedzeniach plenarnych KC PZPR. Chcąc poprawić sytuację życiową obywateli, zamierzano stworzyć rozbudowany system świadczeń społecznych, opiekuńczo-wychowawczych, zdrowotnych, kulturalnych. Rodzina, także niepełna ${ }^{151}$, miała być pod szczególną opieką państwa. Zdawano sobie sprawę, że „najlepszą polityką pronatalistyczną jest dobra polityka społeczna"152.

W dyskusjach o polityce społecznej stale powracał problem niepłaconych alimentów. Czasopisma kobiece publikowały listy przysyłane przez samotne matki. O unikaniu płacenia alimentów i katastrofalnych tego społecznych konsekwencjach pisali publicyści. Na początku lat siedemdziesiątych ożywione dyskusje

\footnotetext{
144 W. Wanatowska, op. cit., s. 77-78.

145 Bank alimentów? A czemu nie dłużnicy państwa, „Przyjaciółka” 13 XII 1971, nr 51.

146 B. Klich-Kluczewska, op. cit., s. 84.

147 Pojęcie „alarm demograficzny” padło w czasie sympozjum, którego zadaniem miało być m.in. określenie celów polityki socjalnej i pronatalistycznej. Wystąpienie Zofii Dębińskiej. Zob.: Socjalne i prawne środki ochrony macierzyństwa i rodziny. Sympozjum..., s. 39.

148 B. Klich-Kluczewska, P. Perkowski, op. cit., s. 362-363.

149 O dalszy socjalistyczny rozwój Polskiej Rzeczypospolitej Ludowej w latach 1971-1975. Uchwała VI Zjazdu Polskiej Zjednoczonej Partii Robotniczej, w: VI Zjazd Polskiej Zjednoczonej Partii Robotniczej 6-11 grudnia 1971. Podstawowe materialy i dokumenty, Warszawa 1972, s. 238-243.

150 M. Latuch, Demograficzne uwarunkowania potrzeb aktywnej polityki społecznej, w: Socjalne i prawne środki..., Warszawa 1976, s. 41.

151 W $1974 \mathrm{r}$. w rodzinach niepełnych wychowywało się ponad 928 tys. dzieci do lat 24. Zob.: M. Jarosz, Dezorganizacja..., s. 82.

152 Taką opinię wygłosił doc. dr. hab. Jan Rosner. Zob.: Socjalne i prawne środki ochrony macierzyństwa i rodziny. Sympozjum..., s. 98.
} 
można było śledzić na łamach „Trybuny Ludu”, „Życia Warszawy”, „Przyjaciółki”, „Kobiety i Życia”, „Zwierciadła”153. W czasie dyskusji w redakcji „Przyjaciółki” nie tylko szukano odpowiedzi na pytanie: „Dlaczego egzekucja alimentów przebiega tak ospale?” Wnioskowano też, aby państwo przejęło wypłacanie alimentów niepłaconych przez ojców. Formułowano konkretne rozwiązania, sięgając przykładowo po rozwiązania stosowane $\mathrm{w}$ Danii ${ }^{154}$. W następnych miesiącach publikowano artykuły o tym, jak z niepłaconymi alimentami radzono sobie w innych państwach ${ }^{155}$. Temat stał się gorący i przebijał się do świadomości społeczeństwa, a i decydentów.

Jak wykazano, także peerelowskie instytucje notowały „niepokojący” napływ listów dotyczących alimentów. W takich okolicznościach Biuro Listów i Inspekcji, korzystając z pomocy Prokuratury Generalnej, związków zawodowych, organizacji kobiecych oraz „komórek listów urzędów centralnych”, przebadało kwestię alimentacji. Efekty tych analiz oraz wynikające $\mathrm{z}$ tego wnioski i postulaty zawarto w obszernej notatce przygotowanej w październiku 1972 r. ${ }^{156}$

Polityczne decyzje podjęte przez centralne gremia PZPR sprzyjały poszukiwaniu sposobów rozwiązania nabrzmiałej kwestii alimentacyjnej. Dyskusje z udziałem ekspertów i publicystów toczono w czasie sympozjum zorganizowanego w kwietniu 1973 r. przez Instytut Pracy i Spraw Socjalnych, którego tematem przewodnim były „Socjalne i prawne środki ochrony macierzyństwa i rodziny”. W czasie obrad projekt "banku alimentacyjnego" uznano za dobry, twierdząc: „Nasze państwo jest stać na to, żeby przejąć obowiązek alimentacyjny wobec każdego dziecka, na rzecz którego sąd nałożył alimenty, jeżeli od rodziców aktualnie nie można ich wyegzekwować". Jeden z dyskutantów, choć generalnie pozytywnie oceniał tę koncepcję, miał jednak wątpliwości i pytał: „czy jest z czego płacić?”157.

$\mathrm{W}$ debatę włączyły się najbardziej zainteresowane sprawą samotne matki. W korespondencji „do Warszawy” przedstawiały swoje doświadczenia, opinie i postulaty. Przykładowo, Jadwiga Dunin z Dusznik-Zdroju proponowała utworzenie banku, który miałby wypłacać alimenty, „a później jak to w innych bankach z dłużnikami, ściągał od nich należne sumy". Matki samotnie wychowujące dzieci i nieotrzymujące alimentów domagały się „zrobienia porządku” z ojcami

153 ODiZP TVP, KdsRiT „Polskie Radio i Telewizja”, BL, 1231/3, „Biuletyn Wewnętrzny” nr 9 (607), kwiecień 1972, O egzekucji alimentów, cz. 1, oprac. red. B. Kwiecień, s. 1; W. Wanatowska, op. cit., s. 78. Przykładowo zob.: Z. Wasilkowska, Dyskusja w redakcji, „Przyjaciółka” 26 III 1972, nr 13 , s. 8.

154 Z. Wasilkowska, Dyskusja w redakcji..., s. 8.

155 O alimentach. Korespondencja z ZSRR i Bułgarii, „Przyjaciółka” 23 IV 1972, nr 17; O alimentach. Korespondencja $z$ Jugosławii i NRD, „Przyjaciółka” 5 V 1972, nr 20.

156 AAN, KC PZPR, XXVII/5, Notatka o niektórych problemach związanych z alimentacją, k. 229239.

157 Wypowiedzi ppłk. Leona Śliwińskiego i prof. Mieczysława Piekarskiego, cyt. za: Socjalne i prawne środki ochrony macierzyństwa i rodziny. Sympozjum..., s. 28, 68. 
niepłacącymi na dzieci. Postulat wprowadzenia organizacyjnych rozwiązań zabezpieczających wypłacanie alimentów powtarzał się w wielu listach. Korespondentki domagały się powołania „Banku Alimentacyjnego” wypłacającego na bieżąco alimenty i egzekwującego zaległe kwoty od dłużników ${ }^{158}$.

Wypłacanie $\mathrm{z}$ funduszy publicznych pieniędzy wierzycielom alimentacyjnym, którzy nie mogli uzyskać ich w postępowaniu egzekucyjnym, było już praktykowane w innych państwach. Prekursorem były kraje skandynawskie. W Norwegii takie rozwiązanie stosowano od 1957 r., w Danii od 1961 r, w Szwecji i Finlandii od 1963 r. ${ }^{159}$ Argumenty na rzecz powołania takiej instytucji w Polsce były przekonujące. O postępie prac informowała m.in. „Kobieta i Życie” $160 \mathrm{i}$ „Przyjaciółka”161.

Wieloletnie zabiegi samotnych matek, dezyderaty formułowane przez urzędy i instytucje zajmujące się problemami niepłaconych alimentów dla małoletnich dzieci były dla władz partyjno-państwowych przesłanką do podjęcia prac nad potrzebną ustawą. Zapowiedział to premier Piotr Jaroszewicz, przemawiając w sejmie 19 stycznia $1974 \mathrm{r}$. Ustawa miała wejść w życie 1 stycznia $1975 \mathrm{r} .{ }^{162}$ Miesiąc później Sejm PRL na posiedzeniu 18 lipca 1974 r. uchwalił ustawę o powołaniu funduszu alimentacyjnego. Zgodnie z zapowiedzią Jaroszewicza nowe rozwiązania prawne miały obowiązywać od początku następnego roku ${ }^{163}$. O przyjęciu ustawy szeroko informowała ówczesna prasa ${ }^{164}$. O tym, że nowa polityka społeczna była rzeczywiście realizowana, świadczą i inne decyzje. W tym samym okresie wprowadzono nowe rozwiązania dotyczące zasiłków rodzinnych ${ }^{165}$, a w kodeksie pracy znalazły się zapisy ułatwiające dochodzenie świadczeń alimentacyjnych ${ }^{166}$.

Warto podkreślić, że w tym samym czasie wypłatę nieregulowanych zobowiązań alimentacyjnych wzięły na siebie władze państwowe Francji i Austrii ${ }^{167}$, a były to państwa bogatsze od Polski. Choćby z tego powodu należy docenić powołanie funduszu alimentacyjnego przez władze PRL.

158 AAN, KC PZPR, XXVII/3, Informacja o listach, które wpłynęły do Biura Listów i Inspekcji w lutym 1973, k. 79.

159 T. Smyczyński, Obowiązek alimentacyjny rodziców względem dziecka a polityka socjalna państwa, Wrocław-Warszawa-Kraków 1978, s. 122.

160 Alimenty, alimenty... Co nowego? „Kobieta i Życie” 6 I 1974, nr 1; Z myśla o rodzinie, „Kobieta i Życie” 3 II 1974, nr 5; Przywileje dla kobiet, „Kobieta i Życie” 10 II 1974, nr 6.

161 E. Wódarska, Fundusz alimentacyjny, „Przyjaciółka” 10 II 1974, nr 6.

162 Rządowy program realizacji postanowień I Krajowej Konferencji PZPR. Przemówienie prezesa Rady Ministrów, Piotra Jaroszewicza na sesji Sejmu PRL w dniu 19 stycznia 1974 r., w: Program realizacji postanowień I Krajowej Konferencji PZPR, Warszawa 1974, s. 35-36.

163 Dz.U. 1974, nr 27, poz. 157.

164 Czekaliśmy na tę ustawę, „Przyjaciółka” 4 VIII 1974, nr 31; Fundusz alimentacyjny, „Prawo i Życie" 1974, nr 30.

165 Zasitki rodzinne po nowemu, „Kobieta i Życie” 4 VIII 1974, nr 31; Reforma zasitków rodzinnych, „Przyjaciółka” 11 VIII 1974, nr 32.

166 Uprawnienia kobiet, „Kobieta i Życie” 25 VIII 1974, nr 34.

167 We Francji stało się to w 1975 r, a w Austrii rok później, T. Smyczyński, Obowiązek..., s. 122. 
Wymiernym i pozytywnym następstwem powołania funduszu była możliwość składania wniosków za pośrednictwem organu zajmującego się egzekucją alimentów do Zakładu Ubezpieczeń Społecznych, który był gwarantem i dystrybutorem świadczeń ${ }^{168}$. Wcześniej, jak wiadomo, PKPS doraźnie wypłacał zaliczki samotnym matkom, które bezskutecznie oczekiwały na alimenty. Fundusz alimentacyjny, co należy podkreślić, wypłacał kwoty ustalone przez sądy. Mocnym dowodem potwierdzającym słuszność czy wręcz konieczność powołania funduszu jest zestawienie sum wsparcia udzielanego przez państwo osobom nieotrzymującym zasądzonych alimentów. W 1973 r. - w roku poprzedzającym powołanie funduszu - PKPS wypłacił 3,5 mln zł. W $1975 \mathrm{r}$. ZUS z funduszu alimentacyjnego wypłacił $192,1 \mathrm{mln} \mathrm{z}^{169}$.

\section{Single Mothers' Letters. The Socio-Political Contexts of the Establishment of the Child Maintenance Fund in 1974 (Summary)}

After the Second World War, the birth rate in Poland increased significantly. A dynamic increase in the number of births occurred in the first post-war decade. Later, even though some fluctuations appeared, until the late 1980s and early 1990s, at least half a million children were born each year. There were also children born out of wedlock (illegitimate children). The moral changes that took place after the war led to an increase in divorces. Another growing phenomenon was children's abandonment by one of the parents (usually the father) and leaving them without anything to live on.

In many cases, fathers did not feel obliged to support their children financially. Even after receiving a court order, they avoided transferring money to single mothers upbringing their children. It eventually led the impoverished mothers to write letters to the central government administration offices. Most of such letters contained grievances and desperate pleas. The examined correspondence consists of descriptions of dramatic struggles for paternity acknowledgement, the obligation of alimony, and enforcement of the due child support amounts. Single mothers complained about the state institutions' incompetent, in their opinion, actions: courts, prosecutors, bailiffs, and the Citizens' Militia (Milicja Obywatelska) against fathers who evaded paying alimonies. Moreover, there was an increase in social awareness of the need to establish institutional means to guarantee single mothers the payment of alimonies by heartless fathers who failed to fulfil that duty. Those single mothers expected such means, and they wrote about it in letters to the central authorities, radio and TV stations, and newspaper editors. The social pressure and some government decisions, in line with the new social policy implemented in the Edward Gierek decade, led to the adoption of the bill establishing the Child Maintenance Fund in 1974.

\section{Bibliografia}

Alimenty, alimenty... Co nowego? „Kobieta i Życie” 6 I 1974, nr 1

Andrzejewski M., Fundusz alimentacyjny. Komentarz do ustawy z dnia 18 lipca 1974 r., Lublin 1995 Bafia J., Miodulski K., Siewierski M., Kodeks karny. Komentarz, Warszawa 1971

168 T. Smyczyński, Fundusz alimentacyjny, „Państwo i Prawo” 1975, nr 1, s. 64; M. Andrzejewski, op. cit., s. 23-25; W. Wanatowska, op. cit., s. 7.

169 M. Andrzejewski, op. cit., s. 18. 
Balcerzak-Paradowska B., Konerska B., Sytuacja społeczna i materialna matek niezamężnych, Warszawa 1983

Bank alimentów? A czemu nie dłużnicy państwa, „Przyjaciółka” 13 XII 1971, nr 51

Bogacka H., Sobieszak A., Rozwody w Polsce w latach 1950-1974 w świetle badań statystycznych, w: Wybrane zagadnienia patologii rodziny, red. M. Jarosz, Warszawa 1976

Czekaliśmy na tę ustawę, „Przyjaciółka” 4 VIII 1974, nr 31

Dach Z., Praca zawodowa kobiet w Polsce w latach 1950-1972 i jej aspekty ekonomiczno-społeczne, Warszawa 1976

Doniec R., Rodzina polska w kulturze realnego socjalizmu. Między ideologią a codziennością, Kraków 2019

Fidelis M., Czy „nowy matriarchat”? Kobiety bez mężczyzn w Polsce po II wojnie światowej, w: Kobieta i rewolucja obyczajowa. Społeczno-kulturowe aspekty seksualności. Wiek XIX i XX. Zbiór studiów, red. A. Żarnowska, A. Szwarc, Warszawa 2006

Fidelis M., Kobiety, komunizm i industrializacja w powojennej Polsce, Warszawa 2015

Fidelis M., Równouprawnienie czy konserwatywna nowoczesność? Kobiety pracujące, w: K. Stańczak-Wiślicz, P. Perkowski, M. Fidelis, B. Klich-Kluczewska, Kobiety w Polsce 1945-1989. Nowoczesność, równouprawnienie, komunizm, Kraków 2020

Fundusz alimentacyjny, „Prawo i Życie” 1974, nr 30

Gersdorf M., Sabat I., Szczepłek W., Zabłocka J., Efektywność egzekucji roszczeń alimentacyjnych oraz sądowe dochodzenie ojcostwa. Wybrane problemy, Warszawa 1976

Graniewska D., Krupa K., Balcerzak-Paradowska B., Samotne matki, samotni ojcowie. O rodzinach niepetnych $w$ Polsce, Warszawa 1986

Hoffman D.L., Mothers in the motherland, Stalinism pronatalism in its pan-European context, „Journal of Social History" 34, 2000, nr 1, s. 34-54

Jarosz D., Listy do Polskiego Radia i Telewizji (1950-1989), w: A.M. Adamus, D. Jarosz, G. Miernik, E. Szpak, Listy do władz centralnych w Polsce 1945-1989 (przewodnik), Warszawa 2019 (https:// rcin.org.pl/ihpan/dlibra/publication/91801/edition/74556, dostęp: 7 I 2022)

Jarosz D., Polacy a stalinizm 1948-1956, Warszawa 2000

Jarosz M., Dezorganizacja w rodzinie i społeczeństwie, Warszawa 1987

Jarosz M., Samotne matki we współczesnym społeczeństwie polskim, w: Polityka społeczna. Uwarunkowania demograficzne, zadania, potrzeby, red. M. Latuch, M. Namysłowska, Warszawa 1980

Jarska N., Kobiety z marmuru. Robotnice w Polsce w latach 1945-1960, Warszawa 2015

Kałwa D., Wyboiste drogi równouprawnienia. Sytuacja kobiet w II Rzeczypospolitej, w: A. Czocher, D. Kałwa, B. Klich-Kluczewska, B. Łabno, Wojna to meska rzecz? Losy kobiet w okupowanym Krakowie w dwunastu odsłonach, Kraków 2011

Klich-Kluczewska B., Perkowski P., Obiekty biopolityki? Zdrowie, reprodukcja i przemoc, w: K. Stańczak-Wiślicz, P. Perkowski, M. Fidelis, B. Klich-Kluczewska, Kobiety w Polsce 1945-1989. Nowoczesność, równouprawnienie, komunizm, Kraków 2020

Klich-Kluczewska B., Rodzina, tabu i komunizm w Polsce 1956-1989, Kraków 2015

Kobiety w Polsce, Warszawa 1975

Kodeks prawa małżeńskiego, rodzinnego i opiekuńczego RSFRR. Tekst urzędowy wedtug stanu na dzień 1 lipca 1950 r. wraz z Dodatkiem zawierajacym materiały do poszczególnych artykułów kodeksu, Warszawa 1951

Korzeniecka K., Samodzielne macierzyństwo - wybór czy konieczność?, „Forum Pedagogiczne” 2014, nr 2, s. $105-116$

Kruszewska J., Współdziałanie zakładów pracy w egzekwowaniu obowiązku alimentacyjnego, „Praca i Zabezpieczenie Społeczne" 1961, nr 7

Kurzynowski A., Macierzyństwo a praca kobiet zamężnych (poza rolnictwem), w: Socjalne i prawne środki ochrony macierzyństwa i rodziny, wybór materiałów D. Graniewska, Warszawa 1976 
Latuch M., Demograficzne uwarunkowania potrzeb aktywnej polityki społecznej, w: Socjalne i prawne środki ochrony macierzyństwa i rodziny, wybór materiałów D. Graniewska, Warszawa 1976

Leksykon polityki społecznej, red. B. Rysz-Kowalczyk, Warszawa 2002

Łobodzińska B., Rodzina w Polsce, Warszawa 1974

Majdański W., Planowanie zaludnienia. Self-control, Łomianki 2004

Miernik G., Listy do centralnych władz Polskiej Zjednoczonej Partii Robotniczej (1950-1989), w: A.M. Adamus, D. Jarosz, G. Miernik, E. Szpak, Listy do władz centralnych w Polsce 19451989 (przewodnik), Warszawa 2019 (https://rcin.org.pl/ihpan/dlibra/publication/91801/edition/74556, dostęp: 7 I 2022)

O alimentach. Korespondencja z Jugosławii i NRD, „Przyjaciółka” 5 V 1972, nr 20

O alimentach. Korespondencja z ZSRR i Bułgarii, „Przyjaciółka” 23 IV 1972, nr 17

O dalszy socjalistyczny rozwój Polskiej Rzeczypospolitej Ludowej w latach 1971-1975. Uchwała VI Zjazdu Polskiej Zjednoczonej Partii Robotniczej, w: VI Zjazd Polskiej Zjednoczonej Partii Robotniczej 6-11 grudnia 1971. Podstawowe materiaty i dokumenty, Warszawa 1972

Perkowski P., Wedded to Welfare? Working Mothers and the Welfare State in Communist Poland, „Slavic Review” 76, 2017, nr 2, s. 455-480

Pielkowa J., Rodzina samotnej matki jako środowisko wychowawcze, Katowice 1983 (Prace Naukowe Uniwersytetu Śląskiego w Katowicach, nr 616)

Pietrzak M., Sytuacja prawna kobiet w Drugiej Rzeczypospolitej, w: Równe prawa i nierówne szanse. Kobiety w Polsce międzywojennej, red. A. Żarnowska, A. Szwarc, Warszawa 2000

Przywileje dla kobiet, „Kobieta i Życie” 10 II 1974, nr 6

Reforma zasiłków rodzinnych, „Przyjaciółka” 11 VIII 1974, nr 32

Rosset E., Rozwody, Warszawa 1986

Rządowy program realizacji postanowień I Krajowej Konferencji PZPR. Przemówienie prezesa Rady Ministrów, Piotra Jaroszewicza na sesji Sejmu PRL w dniu 19 stycznia 1974 r., w: Program realizacji postanowień I Krajowej Konferencji PZPR, Warszawa 1974

Siewierski M., Kodeks karny i prawo o wykroczeniach. Komentarz, Warszawa 1958; Warszawa 1965

Siwik Z., Rozmiary i dynamika spraw o niealimentacje w komisjach PKPS, „Problemy Rodziny” 1972, nr 5

Siwik Z., Statystyczna ocena przestępczości niealimentacyjnej w latach 1954-1974, w: Wybrane zagadnienia patologii rodziny, red. M. Jarosz, Warszawa 1976

Smyczyński T., Fundusz alimentacyjny, „Państwo i Prawo” 1975, nr 1

Smyczyński T., Obowiązek alimentacyjny rodziców względem dziecka a polityka socjalna państwa, Wrocław-Warszawa-Kraków 1978

Socjalne i prawne środki ochrony macierzyństwa i rodziny. Sympozjum - 9 IV 1973. Dyskusja, Warszawa 1973

Tryfan B., Socjalne i prawne środki ochrony macierzyństwa na wsi, w: Socjalne i prawne środki ochrony macierzyństwa i rodziny, wybór materiałów D. Graniewska, Warszawa 1976

Uprawnienia kobiet, „Kobieta i Życie” 25 VIII 1974, nr 34

Wanatowska W., Ochrona prawna roszczeń alimentacyjnych, „Studia Prawno-Ekonomiczne” 18, 1977

Wasilkowska Z., Dyskusja w redakcji, „Przyjaciółka” 26 III 1972, nr 13

Wasilkowska Z., Prawna ochrona rodziny, w: Socjalne i prawne środki ochrony macierzyństwa i rodziny, wybór materiałów D. Graniewska, Warszawa 1976

Winiarz J., Ochrona praw matki, dziecka i rodziny, Warszawa 1954

Wódarska E., Fundusz alimentacyjny, „Przyjaciółka” 10 II 1974, nr 6

Z myśla o rodzinie, „Kobieta i Życie” 3 II 1974, nr 5

Zaremba M., Wielka trwoga. Polska 1944-1947. Ludowa reakcja na kryzys, Kraków 2012

Zasiłki rodzinne po nowemu, „Kobieta i Życie” 4 VIII 1974, nr 31 
Grzegorz Miernik, dr hab., prof. Instytutu Historii Uniwersytetu Jana Kochanowskiego w Kielcach; w badaniach koncentruje się na historii społecznej i gospodarczej Polski po II wojnie światowej; autor monografii: Opór chłopów wobec kolektywizacji w województwie kieleckim 1948-1956, Kielce 1999; „My” i „Oni”. Społeczeństwo Kielecczyzny i stalinowski system władzy, Kielce 2007; współautor (z D. Jaroszem): „Zhańbiona” wieś Okół. Opowieści o buncie, Warszawa-Kielce 2016; współautor (z A.M. Adamus, K. Gajewskim, Á.L. Ispán, D. Jaroszem, C. Kovácsem, E. Szpak), Listy do władzy 1945-1989. Studia przypadków, Warszawa 2019.

Kontakt: grzegorz.miernik@ujk.edu.pl 